\title{
Postmortem Toxicology of New Synthetic Opioids
}

\author{
Marta Concheiro ${ }^{1 *}$, Rachel Chesser ${ }^{1}$, Justine Pardi ${ }^{2}$ and Gail Cooper ${ }^{2}$ \\ ${ }^{1}$ Department of Sciences, John Jay College of Criminal Justice, City University of New York, New York, NY, United States, \\ ${ }^{2}$ Department of Forensic Toxicology, New York Office of the Chief Medical Examiner, New York, NY, United States
}

\section{OPEN ACCESS}

Edited by:

Francesco Paolo Busardò,

Università degli Studi di Roma La

Sapienza, Italy

Reviewed by:

Luke N. Rodda,

University of California, San Francisco,

United States

Salahadin Abdi,

University of Texas MD Anderson

Cancer Center, United States

*Correspondence:

Marta Concheiro

mconcheiro-guisan@jjay.cuny.edu

Specialty section:

This article was submitted to

Neuropharmacology,

a section of the journal

Frontiers in Pharmacology

Received: 13 July 2018 Accepted: 04 October 2018

Published: 26 October 2018

Citation:

Concheiro $M$, Chesser R, Pardi $J$ and

Cooper G (2018) Postmortem

Toxicology of New Synthetic Opioids.

Front. Pharmacol. 9:1210.

doi: 10.3389/fphar.2018.01210
One hundred fifteen Americans die every day from opioid overdose. These overdose fatalities have been augmented by the increased availability of potent synthetic opioids, such as fentanyl and its derivatives. The death rate of synthetic opioids, other than methadone, increased by $72.2 \%$ from 2014 to 2015, and doubled from 2015 to 2016, situating the USA in the midst of an opioid overdose epidemic. The analytical identification of these opioids in postmortem samples and the correct toxicological data interpretation is critical to identify and implement preventive strategies. This article reviews the current knowledge of postmortem toxicology of synthetic opioids and the chemical and pharmacological factors that may affect drug concentrations in the different postmortem matrices and therefore, their interpretation. These factors include key chemical properties, essential pharmacokinetics parameters (metabolism), postmortem redistribution and stability data in postmortem samples. Range and ratios of concentrations reported in traditional and non-traditional postmortem specimens, blood, urine, vitreous humor, liver and brain, are summarized in tables. The review is focused on fentanyl and derivatives (e.g., acetyl fentanyl, butyryl fentanyl, carfentanil, furanyl fentanyl, 4-methoxybutyrylfentanyl, 4-fluorobutyrylfentanyl, ocfentanil) and non-traditional opioid agonists (e.g., AH-7921, MT-45, U-47700). All of these data are critically compared to postmortem data, and chemical and pharmacological properties of natural opioids (morphine), semi-synthetic (oxycodone, hydrocodone, hydromorphone, and oxymorphone), and synthetic opioids (methadone and buprenorphine). The interpretation of drug intoxication in death investigation is based on the available published literature. This review serves to facilitate the evaluation of cases where synthetic opioids may be implicated in a fatality through the critical review of peer reviewed published case reports and research articles.

\section{Keywords: opioids, synthetic opioids, fentanyl, postmortem toxicology, blood}

\section{INTRODUCTION}

Opioid overdose deaths continue to increase in the United States, killing more than 42,000 people in 2016. The opioids detected in these cases, in increasing order, were methadone, natural and semi-synthetic opioids (e.g., oxycodone, hydrocodone), heroin and synthetic opioids (e.g., fentanyl, fentanyl-analogs). Synthetic opioids (excluding methadone) and heroin deaths specifically experienced a sharp increase from 2015 to 2016 (20 and 100\%, respectively) (Seth et al., 2018). Fentanyl and its derivatives have been increasingly present as adulterants mainly in heroin, 
but also in other drugs such as cocaine and synthetic cannabinoids (Coopman and Cordonnier, 2017; Armenian et al., 2018), due to their ease of manufacturing and readily available precursors shipped from China (Armenian et al., 2018). In addition to being present in other drugs supply, fentanyl analogs have been also marketed as "research chemicals" and can easily be acquired over the internet. Due to their high potency and the increased use of heroin as an initiating opioid of abuse (8.7\% in 2005 vs. $33.3 \%$ users in 2015) (Cicero et al., 2017; O'Donnell et al., 2017), the number of opioid-related deaths have drastically increased in the recent years. Given that opioid novices have limited tolerance to opioids, a slight imprecision in dosing inherent in heroin use and/or the presence of potent fentanyl and analogs, can be fatal.

Fentanyl, its analogs (e.g., acetyl fentanyl, 3-methylfentanyl, alphamethylfentanyl, furanyl fentanyl) and the new generation synthetic opioids (e.g., AH-7921, U-47700, MT-45) have a chemical core structure totally different from morphine, a naturally occurring opioid from Papaver somniferum and reference compound of the opioids group; but all of them act on the opioid receptor (mu-receptor) reducing the intensity of pain and showing a high addiction potential. These opioid receptor agonists also induce dose-dependent respiratory depression (Pattinson, 2008), which is the main reason for their lifethreatening risk (Ujváry et al., 2017). Fentanyl is approximately 200 times more potent than morphine, and the potencies of its analogs are variable, from 7 times more potent than morphine for butyrfentanyl and furanyl fentanyl, to more than 4,000 and 10,000 times for sufentanil and carfentanil, respectively (UNODC, 2017). The new generation opioids AH-7921 and MT-45 show similar potency to morphine (Brittain et al., 1977; EMCDDA, 2015), and U-47700 about 7.5 times more potent (Cheney et al., 1985).

Synthetic opioids are widely regulated by the United States Controlled Substances Act of 1970 (CSA) in order to control their use and distribution. As new compounds arise and threaten public safety, compounds can be emergency scheduled by the DEA to slow production and use of these harmful substances and aid in prosecution of drug diverters for a temporary period until the formal procedures have gone through (US Drug Enforcement Administration, 2017). Substances are classified into schedules in the CSA based on their safety, medicinal use and potential for abuse. A Schedule I substance is classified as having no currently accepted medical use and a high abuse potential. Examples of synthetic opioids in Schedule I include furanyl fentanyl, U-47700, acetyl fentanyl and 3-methyl fentanyl. Schedule II classified opioids have a high potential for abuse but have current medicinal uses like fentanyl which is used as an anesthetic and analgesic, as well as carfentanil, remifentanil and sufentanil (US Drug Enforcement Administration, 2017). Most recently, the DEA issued a temporary scheduling order for all fentanyl -related substances (to include all analog modifications) in February of 2018, which cover all substances that were not already classified into Schedule I of the CSA in an aggressive attempt to regulate the manufacture and subsequent trafficking of new synthetic opioids into the United States (Drug Enforcement Administration, 2018).
The expansion of these new synthetic opioids constitutes an important challenge in forensic toxicology. First of all, most of these substances are not detected in the routine screening and confirmation methods in the laboratory. Also, due to the low doses employed of these highly potent drugs, the concentrations expected in the biological samples are in the low $\mathrm{ng}$ to $\mathrm{pg} / \mathrm{mL}$ or $\mathrm{ng}$ to $\mathrm{pg} / \mathrm{g}$ range, requiring extremely sensitive methods of analysis. Recently, Marchei et al. (2018) and Liu et al. (2018) reviewed the currently available screening and confirmation methods of new synthetic opioids in biological and non-biological samples. As indicated by Marchei et al. (2018), gas chromatography combined with mass spectrometry (GC-MS) and more frequently liquid chromatography tandem mass spectrometry (LC-MSMS) are the most common techniques due to their sensitivity and specificity. However, given the continued development of new derivatives, the major disadvantage of these target techniques, which employ quadrupole mass spectrometers, is that are limited by the reference standards available. High resolution mass spectrometry (time-of-flight, orbitrap) offers potential advantages to identify unknown compounds without the availability of a reference standard, but this technology is not readily available in most forensic laboratories (Marchei et al., 2018).

Regarding biological samples, most of these methods have been developed in blood or urine, and the target analytes are the parent compounds and rarely the metabolites (Marchei et al., 2018). In postmortem toxicology, other biological specimens such as vitreous humor, liver and brain are commonly analyzed. Unfortunately, fully validated methods for the determination of synthetic opioids in these specimens are lacking in the literature. This is in part due to the constant changes in illicit synthetic opioids being identified and laboratories being unable to justify the extensive time and cost associated with fully validating a method for a drug that may only be present in cases for a short time. Analytical methods in forensic toxicology are commonly validated in the corresponding biological sample following the guidelines published by the Scientific Working Group in Forensic Toxicology (SWGTOX) (Scientific Working Group for Forensic Toxicology, 2013) to guarantee the analytical quality of the measured concentrations. The analysis of metabolites in the different biological matrices may improve the interpretation of the results, extending the detection window and indicating if it was an acute or a delayed-death evaluating the metaboliteto-parent ratios. Recent publications about the identification of new metabolites of the synthetic opioids are available (Wohlfarth et al., 2016; Steuer et al., 2017; Watanabe et al., 2017; Krotulski et al., 2018a); however, its application to authentic samples is still scarce (Poklis et al., 2015; Staeheli et al., 2016; Martucci et al., 2017; Allibe et al., 2018).

Besides the analytical challenges associated with synthetic opioids, due to the scarcity of available postmortem data, the interpretation of the results is extremely difficult. Conducting postmortem toxicology interpretation provides a number of very significant challenges to the forensic toxicologist. The range of postmortem specimens (blood, urine, vitreous humor, tissues, hair), the lack of reference databases, the presence of other substances (e.g., benzodiazepines, alcohol), opioid tolerance, 
and postmortem phenomena (postmortem redistribution and drug instability) complicates the interpretation of the analytical findings. Pichini et al. (2018) and Zawilska (2017) discussed nonfatal and lethal intoxications involving the new synthetic opioids, and Drummer (2018) focused his review on fatalities due to these compounds.

The present review is focused on fentanyl derivatives and new generation opioids due to the limited knowledge concerning these substances and their high prevalence in opioid-overdose related cases. This work complements the previously published literature reviewing the current knowledge of postmortem toxicology of synthetic opioids and the chemical and pharmacological factors that may affect drug concentrations in the different matrices and therefore, their interpretation in postmortem samples. These factors include key chemical properties, essential pharmacokinetics parameters, postmortem redistribution and stability data in postmortem samples. All of these data are critically compared to postmortem data of natural opioids (morphine), semi-synthetic (oxycodone, hydrocodone, hydromorphone, and oxymorphone), and synthetic opioids (methadone and buprenorphine). The interpretation of drug intoxication in death investigation is based on the available published literature. This review serves to facilitate the evaluation of cases where synthetic opioids may be implicated in a fatality through the review of peer reviewed published case reports and research articles.

\section{METHODS}

PubMed, Scopus and Google Scholar were searched for appropriate articles. Forensic case-reports and research articles of natural, semi-synthetic and synthetic opioids were reviewed up to May 2018. All articles were manually reviewed for content and references in each manuscript were further queried. Included articles were limited to peer-reviewed journals indexed by the Institute for Scientific Information (ISI) and published in English. Chemical properties were retrieved from the public databases PubChem (https://pubchem.ncbi.nlm.nih.gov/) and DrugBank (https://www.drugbank.ca/drugs).

\section{CHEMICAL AND PHARMACOLOGICAL PROPERTIES}

The chemical structure of the diverse synthetic opioids, including fentanyl and analogs, differs significally from the chemical structure of morphine and semi-synthetic opioids (e.g., oxycodone, hydrocodone, buprenorphine). Figure 1 summarizes the chemical structure of selected classic opioids. Fentanyl is a piperidinyl derivative with moieties on the nitrogen and the 4-position (Figure 2). The different fentanyl derivatives show substitutions on the propionyl moiety (e.g., acetylfentanyl, acrylfentanyl, butyrfentanyl, furanyl fentanyl), phenethyl moiety (e.g., ohmefentanyl), N-phenyl ring (e.g., ocfentanil, 4-methoxybutyrylfentanyl) and/or at the 4-piperidinyl-position (e.g., carfentanil). The chemical structures of the new generation synthetic opioids (AH-7921, U-47700, MT-45) are different from fentanyl. Figure 3 shows 20 fentanyl derivatives and 3 new generation synthetic opioids not related to fentanyl. Due to the close chemical structure among fentanyl derivatives, some compounds, such as cyclopropyl fentanyl and crotonyl fentanyl, have exactly the same molecular formula, and therefore, the same molecular weight. As a consequence of this, special attention has to be paid in the development of the analytical methods for the determination of these compounds, and a complete chromatographic separation is required to guarantee their correct identification by gas or liquid chromatography coupled to mass spectrometry (GC-MS, LC-MSMS).

Chemically, opioids are predominantly basic drugs with $\mathrm{pKa}$ ranging from 7.5 to 10.9 . The chemical parameter $\log \mathrm{P}$, the decimal logarithm of the partition coefficient $\mathrm{Kp}$, is a useful
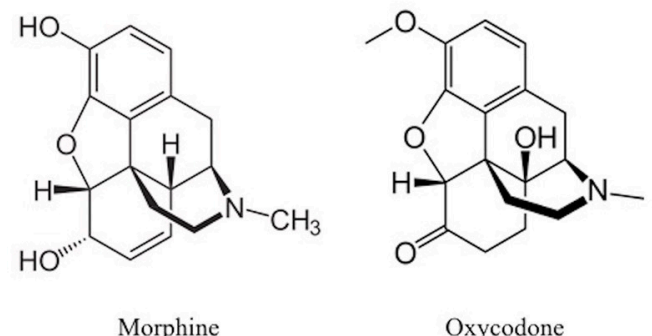

Morphine

Oxycodone

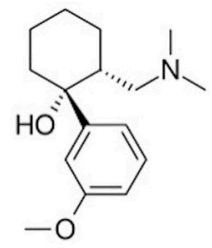

(1R, 2R)-Tramadol

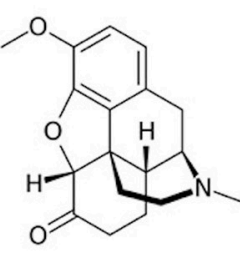

Hydrocodone

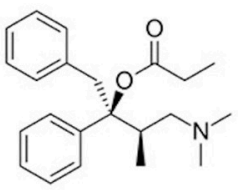

Dextropropoxyphene

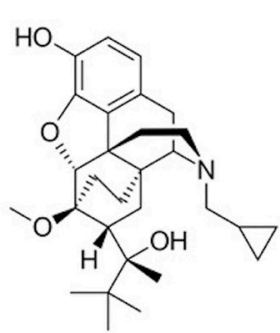

Buprenorphine

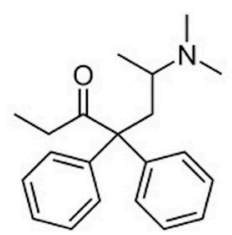

Methadone

FIGURE 1 | Chemical structures of selected classic opioids. 


\section{Fentanyl}

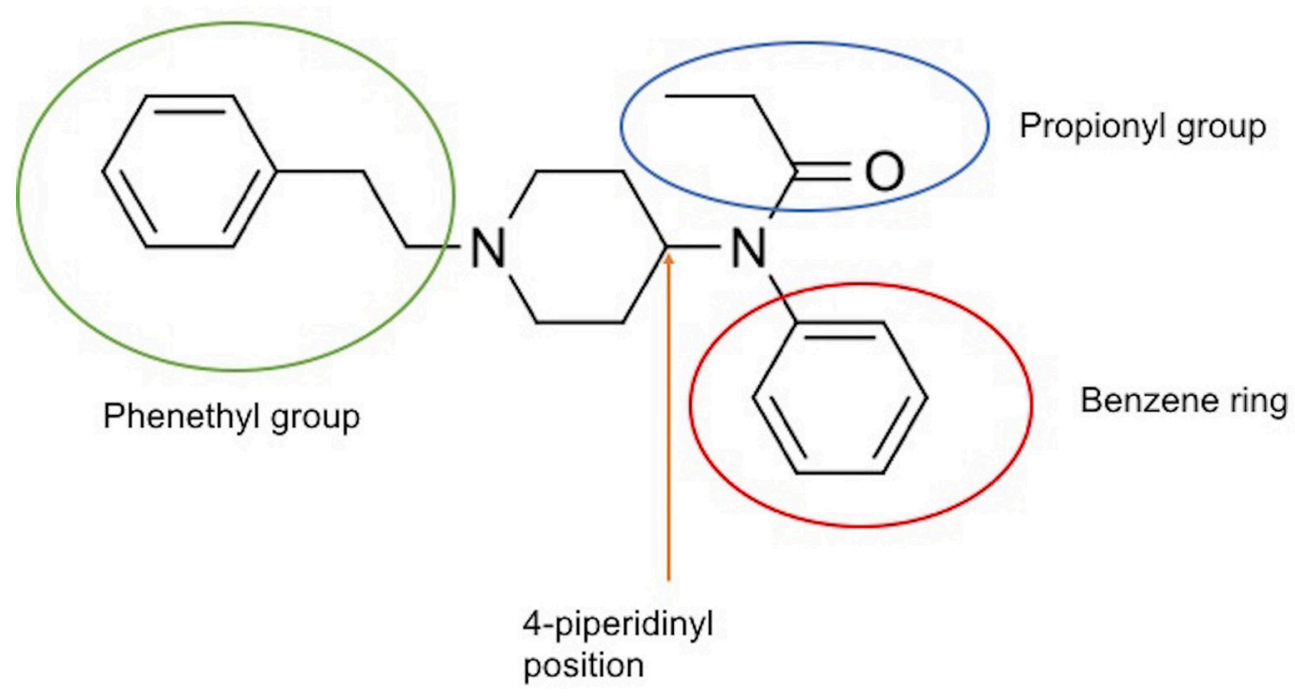

FIGURE 2 | Chemical structure of fentanyl.

indication of the lipophilicity of a compound. In the case of opioids, $\log \mathrm{P}$ range is wide, from 0.8 (oxymorphone) to 5 (methadone). Morphine and related compounds show the lowest $\log P$ values $(0.8-2)$. Fentanyl and analogs show a $\log P$ between 1.5 and 4.3. The high lipophilicity of fentanyl and its analogs enables rapid diffusion through membranes, including the bloodbrain barrier. Also, this lipophilicity along with their basic characteristics make these group of drugs candidates to undergo postmortem redistribution. Table 1 summarizes the molecular weight, pKa and $\log \mathrm{P}$ of selected opioids.

Volume of distribution $(\mathrm{Vd})$ and protein binding also help to predict the drugs that may exhibit postmortem redistribution. $\mathrm{Vd}$ is defined as the volume into which the total amount of the drug would have to be uniformly distributed to reach the concentrations measured in plasma. It is expressed in $\mathrm{L} / \mathrm{kg}$ of body weight (amount of drug in the body divided by the plasma drug concentration). Drugs highly bound to plasma proteins but not to tissue components would be expected to have a small $\mathrm{Vd}$, while those drugs which distribute into muscle, adipose tissue and other intracellular components will have a high Vd. Drugs with a Vd greater than $3 \mathrm{~L} / \mathrm{kg}$ are considered to have a greater potential to undergo postmortem redistribution. Table 2 summarizes the $\mathrm{Vd}$ and protein binding data currently available for selected opioids.

One of the critical issues related to fentanyl, its derivatives and the new synthetic opioids, is the low concentrations expected in the biological samples (ng to $\mathrm{pg} / \mathrm{mL}$ or $\mathrm{ng}$ to $\mathrm{pg} / \mathrm{g}$ range) due to their high potency. However, the potency of these type of drugs varies considerably within this group, and therefore the concentrations reported show a wide range, depending on the drug. Table 2 summarizes the potencies relative to morphine for selected opioids.

\section{METABOLISM}

The identification and quantification of metabolites in postmortem samples may improve the interpretation of the analytical results. The determination of metabolites may extend the window of detection, and also can be employed to calculate metabolite-to-parent ratios in urine and other biological samples to differentiate acute or delayed death. In certain cases, as it happens in morphine and buprenorphine, metabolites can be pharmacologically active. Although this type of information is limited in the case of the synthetic opioids, fentanyl, sufentanil, and alfentanil's metabolites are inactive in the opioid system (Schneider and Brune, 1986).

Although the utility of metabolite determination in biological samples is known, its application to authentic specimens is still scarce in the case of synthetic opioids due to the limited data available about their metabolism (Poklis et al., 2015; Staeheli et al., 2016; Martucci et al., 2017; Allibe et al., 2018). Recent publications about the identification of new metabolites of the synthetic opioids in vivo and in vitro are available (Wohlfarth et al., 2016; Steuer et al., 2017; Watanabe et al., 2017; Krotulski et al., 2018a). While in vitro studies utilizing human liver hepatocytes or microsomes can identify multiple primary and secondary metabolites for a particular fentanyl derivative, actual human specimens typically show lower number and/or a different metabolite prevalence profile, so studies investigating the presence of the in vitro metabolites in authentic human samples are highly encouraged. Table 3 summarizes recent publications about the identification of new metabolites of synthetic opioids in vitro and in vivo.

Fentanyl-derivatives metabolism studies showed similarities and differences from fentanyl metabolism pathways and 

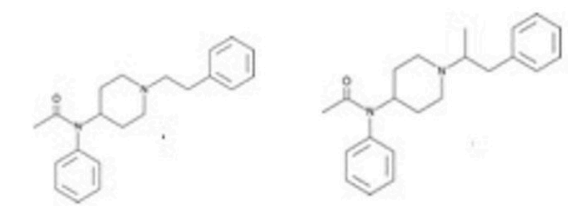

Acetyl fentanyl

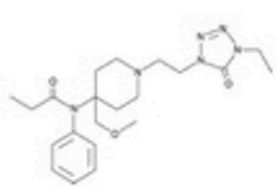

Alfentanyl

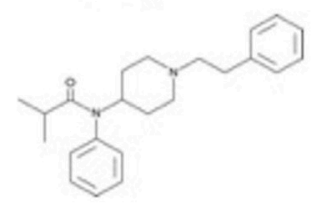

Isobutyrylfentannyl

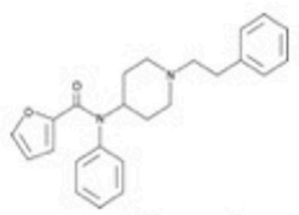

Furanyl fentanyl

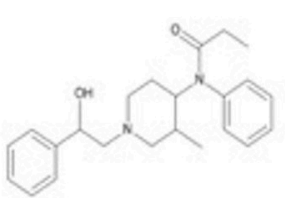

Ohmefentanyl

(beta-hydroxyl-3methylfentanyl)

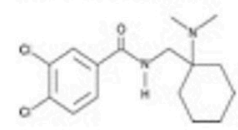

AH-7921 -acetyl fentanyl

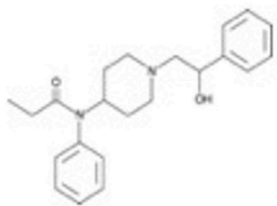

Beta-hydroxyl fentanyl

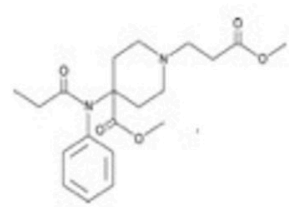

Remifentanyl<smiles>CC(C)C1CCCCC1N(C)C(=O)c1ccc(O)c(O)c1</smiles>

$\mathrm{U}-47700$
Alfa-methyl

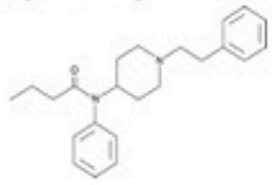

Butyryl fentanyl

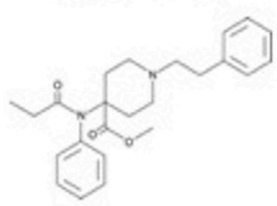

Carfentanil

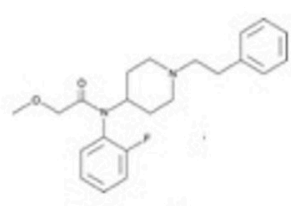

Ocfentanil

(2-fluoro Methoxyacetyl fentanyl)

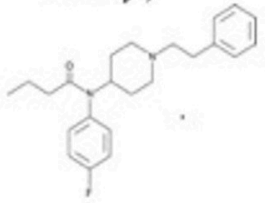

4-fluorobutyryl fentanyl

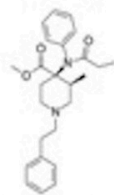

Lofentanil (3-methyl-carfentanil)

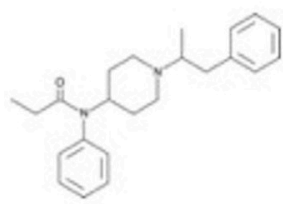

alfa-methylfentanyl

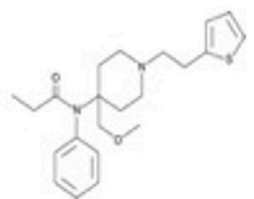

Sufentanil

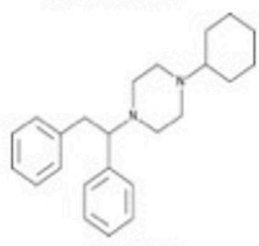

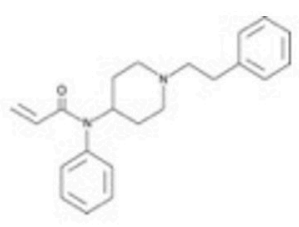

Acrylfentanyl

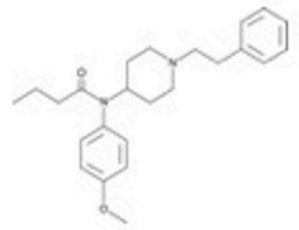

4-methoxy-butyryl fentanyl

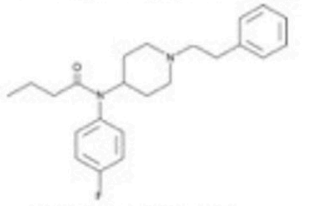

4-fluorofentanyl

(4-FBF; para-

fluorofentanyl)

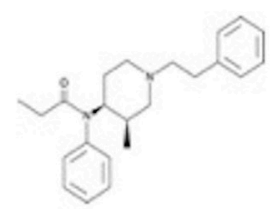

Cis-3-methylfentanyl (3-MF; mefentanyl)

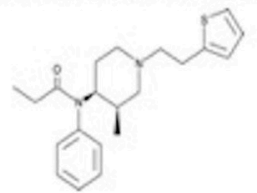

Cis-3-methyl-thiofentanyl

FIGURE 3 | Chemical structures of 20 fentanyl derivatives and 3 new generation opioids not related to fentanyl.

rates. These different metabolic pathways observed for certain derivatives, demonstrate the need to perform individual metabolism studies for each new compound. In the case of fentanyl, only less than $8 \%$ of fentanyl is excreted unchanged. Approximately $85 \%$ of the dose is excreted within $72 \mathrm{~h}$ in feces and urine, the majority as metabolites mainly as norfentanyl generated by $\mathrm{N}$-dealkylation at the piperidine nitrogen (McClain and Hug, 1980). Minor fentanyl metabolites are despropionylfentanyl, also known as 4-ANPP, which is formed by carboxamide hydrolysis, and hydroxyfentanyl and hydroxynorfentanyl metabolites, both hydroxylated at the propionyl moiety (Goromaru et al., 1984; Mahlke et al., 2014).

Several synthetic opioids follow a similar metabolic pathway to fentanyl. Alfentanil undergoes piperidine N-dealkylation to noralfentanil (Meuldermans et al., 1988). Major alphamethylfentanyl metabolites in rats were norfentanyl and 
TABLE 1 | Monoisotopic molecular weight (g/mol), pKa and Log P of selected natural, semi-synthetic and synthetic opioids.

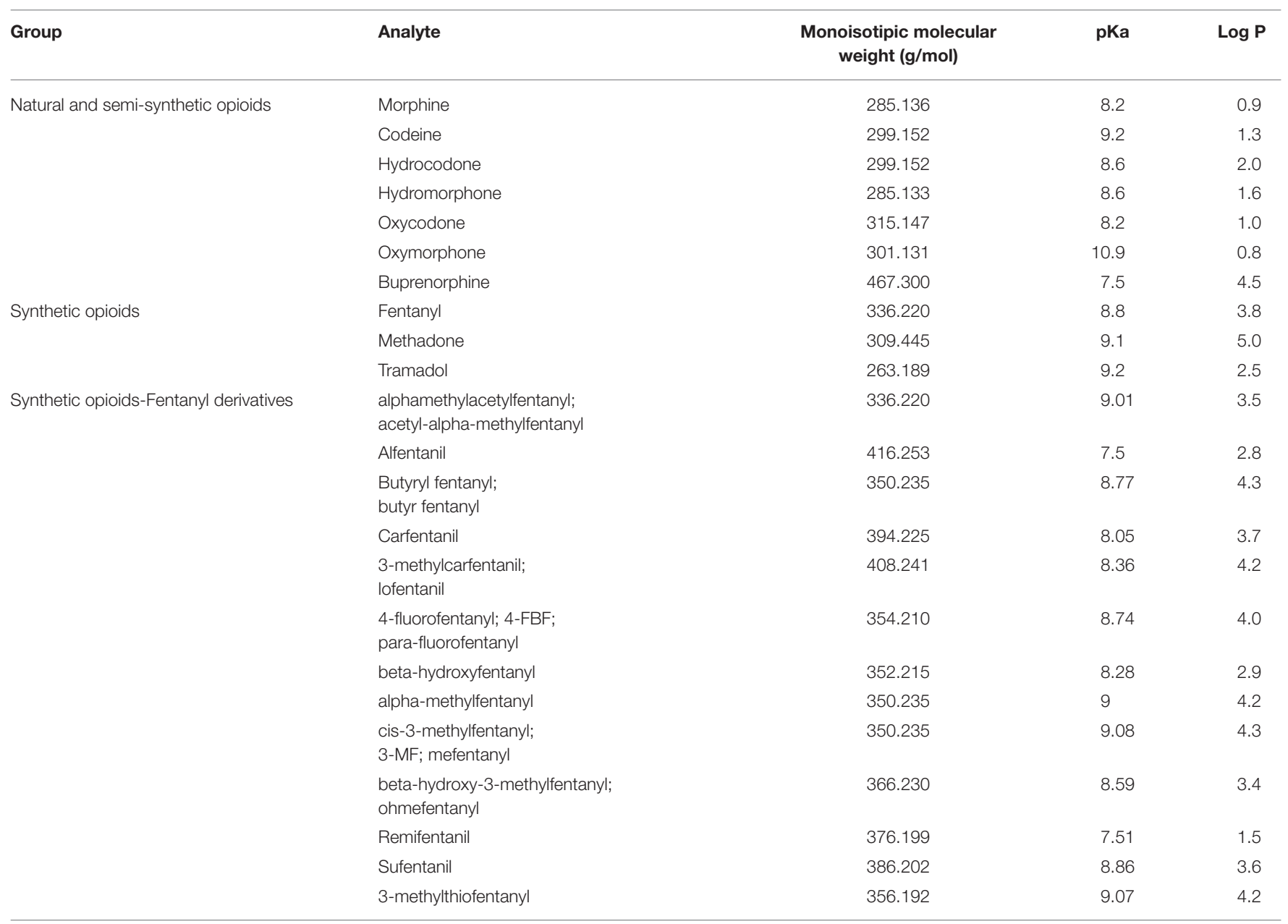

hydroxypropionyl norfentanyl metabolites, exactly as fentanyl (Sato et al., 2010). Meyer et al. (2012) investigated the metabolism in rats of isofentanyl and 3-methyl fentanyl. After the administration of suspected recreational doses, the parent drugs could not be detected in urine and their common nor-metabolite was the predominant compound.

Patton et al. (2014) detected high concentrations of acetylfentanyl and acetyl norfentanyl (>16,500 ng/mL, $180 \mathrm{~min}$ post-dose) in urine samples from rats treated with a toxic dose of acetylfentanyl (3 mg/kg); however, Melent'ev et al. (2015), showed that the main pathway of the biotransformation of acetylfentanyl was hydroxylation by the phenylethyl moiety rather than $\mathrm{N}$-dealkylation in authentic human samples. Melent'ev et al. (2015) and Watanabe et al. (2017) recommended as target analytes in human urine hydroxy-methoxy at phenylethyl moiety and monohydroxylated metabolites, although the reported hydroxylation position in both publications was different. In both publications, the parent compound acetylfentanyl was highly abundant in urine samples, indicating that the parent drug is a suitable target.

Acrylfentanyl underwent $\mathrm{N}$-dealkylation at the piperidine nitrogen producing the major nor-metabolite (Watanabe et al., 2017). The parent compound was also detected at high concentrations in urine samples. N-Dealkylation and monohydroxylation of the piperidine ring were the dominant metabolic pathways for carfentanil in vitro (Feasel et al., 2016). In that study, the authors observed a slow parent depletion in the hepatocytes. For 4-fluoroisobutyrylfentanyl the main metabolites identified in urine were the nor-metabolite, and monohydroxy metabolites at the piperidine ring or at the ethyl linker, as well as the parent compound. In terms of specificity, Watanabe et al., recommended as target compounds in urine the monohydroxy metabolites and the hydroxymethoxy metabolite (Watanabe et al., 2017).

In the case of butyrfentanyl, hydroxylation of the butanamide side chain followed by subsequent oxidation to the carboxylic acid represented the major metabolic step (Steuer et al., 2017). Although the norbutyrfentanyl was not among the most abundant metabolites in human samples in that study, the authors suggested its inclusion as a recommended target analyte because it showed a high intensity in the in vitro experiment. In authentic postmortem blood and urine samples, butyrfentanyl was still detected at 66 and $1,000 \mathrm{ng} / \mathrm{mL}$, respectively. 
TABLE 2 | Critical pharmacological properties in postmortem toxicology, volume of distributon (Vd), protein bining and potency relative to morphine, of selected natural, semi-synthetic and synthetic opioids.

\begin{tabular}{|c|c|c|c|c|c|}
\hline Group & Analyte & Vd (L/kg) & Protein binding (\%) & $\begin{array}{l}\text { Potency relative to } \\
\text { morphine }\end{array}$ & References \\
\hline \multirow{7}{*}{$\begin{array}{l}\text { Natural and } \\
\text { semi-synthetic opioids }\end{array}$} & Morphine & $1-6$ & $30-40$ & 1 & Baselt, 2017 \\
\hline & Codeine & $2.5-3.5$ & $7-25$ & 0.3 & Baselt, 2017 \\
\hline & Hydrocodone & $3.3-4.7$ & $19-45$ & $0.5-1$ & $\begin{array}{l}\text { Patanwala et al., 2007; Baselt, } \\
2017\end{array}$ \\
\hline & Hydromorphone & 2.9 & 20 & $5-10$ & $\begin{array}{l}\text { Bruera et al., 1996; Patanwala } \\
\text { et al., 2007; Baselt, } 2017\end{array}$ \\
\hline & Oxycodone & 2.6 & 45 & 1 & $\begin{array}{l}\text { Patanwala et al., 2007; } \\
\text { Al-Asmari et al., } 2009\end{array}$ \\
\hline & Oxymorphone & 3 & $10-12$ & 10 & $\begin{array}{l}\text { Patanwala et al., 2007; Smith, } \\
2009\end{array}$ \\
\hline & Buprenorphine & $3-5$ & 96 & 40 & Dahan et al., 2005 \\
\hline \multirow[t]{3}{*}{ Synthetic opioids } & Fentanyl & $3-8$ & 80-85 & 224 & Jumbelic, 2010 \\
\hline & Methadone & $1-8$ & $85-90$ & $3-5$ & $\begin{array}{l}\text { Patanwala et al., 2007; Baselt, } \\
2017\end{array}$ \\
\hline & Tramadol & 3 & 20 & 0.1 & $\begin{array}{l}\text { Christoph et al., 2007; Oertel } \\
\text { et al., } 2011\end{array}$ \\
\hline \multirow{11}{*}{$\begin{array}{l}\text { Synthetic opioids-Fentanyl } \\
\text { derivatives }\end{array}$} & Acetylfentanyl & NA & NA & 15 & Higashikawa and Suzuki, 2008 \\
\hline & Acrylfentanil & NA & NA & 170 & Ujváry et al., 2017 \\
\hline & Alfentanil & $0.4-1$ & 92 & 72 & Vardanyan and Hruby, 2014 \\
\hline & Butyryl fentanyl; butyr fentanyl & NA & NA & 7 & Higashikawa and Suzuki, 2008 \\
\hline & Isobutyrylfentanyl & NA & NA & $1.3-6.9$ & Higashikawa and Suzuki, 2008 \\
\hline & Carfentanil & NA & NA & 10,000 & Van Bever et al., 1976 \\
\hline & Furanyl fentanyl & NA & NA & 7 & Higashikawa and Suzuki, 2008 \\
\hline & alpha-methylfentanyl & NA & NA & 56.9 & Higashikawa and Suzuki, 2008 \\
\hline & $\begin{array}{l}\text { cis-3-methylfentanyl; 3-MF; } \\
\text { mefentanyl }\end{array}$ & NA & NA & 6000 & Higashikawa and Suzuki, 2008 \\
\hline & Remifentanil & 0.35 & 70 & 220 & Wax et al., 2003 \\
\hline & Sufentanil & NA & NA & 4,520 & Niemegeers et al., 1976 \\
\hline \multirow{3}{*}{$\begin{array}{l}\text { Synthetic opioids-Not } \\
\text { related to fentanyl }\end{array}$} & $\mathrm{AH}-7921$ & NA & NA & 1 & Hayes and Tyers, 1983 \\
\hline & $\cup-47700$ & NA & NA & 7.5 & Cheney et al., 1985 \\
\hline & MT-45 & NA & NA & 1 & EMCDDA, 2015 \\
\hline
\end{tabular}

NA, not available.

Furanylfentanyl contains a furan group that affects its metabolic profile. This structure seemed to favor the amide hydrolysis, which is the main metabolite in vitro and in vivo (Watanabe et al., 2017). In terms of specificity of the target metabolites, Watanabe et al. (2017) recommended the dihydrodiol-metabolite and Goggin et al. (2017) recommended the same metabolite, as well as the sulfate of the metabolite that results from the amide hydrolysis. As it happened with butyrfentanyl (Steuer et al., 2017), the hepatocyte experiment also suggested high prevalence for the nor-metabolite, which was not significantly present in the authentic urine samples, illustrating the need to analyze human specimens. Furanylfentanyl parent compound was detected in authentic urine samples. For ocfentanyl, the predominant metabolite detected in blood, along with the parent drug, was the O-desmethylated metabolite (Allibe et al., 2018).
In the case of the new synthetic opioids not structurally related to fentanyl, different metabolic pathways has been reported. For AH-7921, the preferred metabolic sites were the amine function and the cyclohexyl ring. The two most dominant metabolites after hepatocyte incubation (also identified in a urine case specimen) were desmethyl and di-desmethyl AH7921. Together with the glucuronidated metabolites, they were recommended as suitable analytical targets for documenting AH-7921 intake (Wohlfarth et al., 2016). In the case of MT-45, Montesano et al reported hydroxy-MT-45-glucuronide and di-hydroxy-MT-45-glucuronide as the most abundant metabolites in rat urine, while the parent drug was found at concentrations $<10 \mathrm{ng} / \mathrm{mL}$ after $300 \mathrm{~min}$ (Montesano et al., 2017). Although similar in chemical structure, U-47700 and U49900 showed specific metabolites. N-Desmethyl-U-47700 was identified as the major metabolite in human urine specimens, 
TABLE 3 | In vitro and in vivo metabolism of synthetic opioids.

\begin{tabular}{|c|c|c|c|c|c|c|c|}
\hline Compound & $\begin{array}{l}\text { Study } \\
\text { type }\end{array}$ & $\begin{array}{l}\text { Matrix } \\
\text { (species) }\end{array}$ & $\begin{array}{l}\text { Total \# } \\
\text { phase I } \\
\text { metabolites }\end{array}$ & $\begin{array}{l}\text { Major metabolites } \\
\text { (decreasing order of } \\
\text { relative intensity) }\end{array}$ & $\begin{array}{l}\text { Phase II } \\
\text { metabolites }\end{array}$ & $\begin{array}{l}\text { Recommended } \\
\text { target analytes } \\
\text { in urine }\end{array}$ & References \\
\hline & In vitro & $\begin{array}{l}\text { Pool human } \\
\text { liver } \\
\text { hepatocytes }\end{array}$ & 7 & $\begin{array}{l}\text { - N-dealkylated } \\
\text { metabolite at the } \\
\text { piperidine moiety } \\
\text { - Hydroxylated } \\
\text { metabolites at the } \\
\text { ethyl linker } \\
\text { - Dihydroxylation at } \\
\text { phenylethyl ring }\end{array}$ & & & $\begin{array}{l}\text { Watanabe } \\
\text { et al., } 2017\end{array}$ \\
\hline & In vitro & $\begin{array}{l}\text { Pluripotent } \\
\text { stem } \\
\text { cell-derived } \\
\text { hepatocytes }\end{array}$ & 6 & $\begin{array}{l}\text { - N-dealkylated } \\
\text { metabolite at the } \\
\text { piperidine moiety } \\
\text { - Hydroxylated } \\
\text { metabolite at } \\
\text { phenylethyl ring } \\
\text { - Hydroxylated } \\
\text { metabolites at the } \\
\text { ethyl linker }\end{array}$ & & & $\begin{array}{l}\text { Kanamori } \\
\text { et al., } 2018\end{array}$ \\
\hline Acrylfentanyl & In vivo & Urine (human) & 12 & $\begin{array}{l}\text { - N-dealkylated } \\
\text { metabolite the } \\
\text { piperidine moiety } \\
\text { - Hydroxylated at the } \\
\text { ethyl linker } \\
\text { - Dihydroxylated } \\
\text { metabolite at the } \\
\text { piperidine and at the } \\
\text { ethyl linker } \\
\text { - Hydroxy-methoxy } \\
\text { metabolite at } \\
\text { phenylethyl ring }\end{array}$ & $\begin{array}{l}\text { Glucuronides of } \\
\text { hydroxy- } \\
\text { metabolites }\end{array}$ & $\begin{array}{l}\text { - Hydroxylated at } \\
\text { the ethyl linker } \\
\text { - Dihydroxylated } \\
\text { metabolite at } \\
\text { the piperidine } \\
\text { and at the ethyl } \\
\text { linker } \\
\text { - Acrylfentanyl }\end{array}$ & \\
\hline Butyrfentanyl & In vitro & $\begin{array}{l}\text { Human liver } \\
\text { microsomes }\end{array}$ & 36 & $\begin{array}{l}\text { - N-dealkylated } \\
\text { metabolite } \\
\text { - Hydroxy-metabolite } \\
\text { at butanamide chain } \\
\text { - Dihydroxy-metabolite } \\
\text { at phenylethyl ring }\end{array}$ & & & $\begin{array}{l}\text { Steuer et al., } \\
2017\end{array}$ \\
\hline
\end{tabular}


TABLE 3 | Continued

\begin{tabular}{|c|c|c|c|c|c|c|c|}
\hline Compound & $\begin{array}{l}\text { Study } \\
\text { type }\end{array}$ & $\begin{array}{l}\text { Matrix } \\
\text { (species) }\end{array}$ & $\begin{array}{l}\text { Total \# } \\
\text { phase I } \\
\text { metabolites }\end{array}$ & $\begin{array}{l}\text { Major metabolites } \\
\text { (decreasing order of } \\
\text { relative intensity) }\end{array}$ & $\begin{array}{l}\text { Phase II } \\
\text { metabolites }\end{array}$ & $\begin{array}{l}\text { Recommended } \\
\text { target analytes } \\
\text { in urine }\end{array}$ & References \\
\hline & & $\begin{array}{l}\text { Blood } \\
\text { (human) }\end{array}$ & & $\begin{array}{l}\text { - Carboxy-metabolite } \\
\text { at butanamide chain }\end{array}$ & & & \\
\hline Carfentanil & In vitro & $\begin{array}{l}\text { Pool human } \\
\text { liver } \\
\text { hepatocytes }\end{array}$ & 11 & $\begin{array}{l}\text { - Monohydroxylated } \\
\text { metabolite at of } \\
\text { piperidine ring } \\
\mathrm{N} \text {-dealkylated } \\
\text { metabolite }\end{array}$ & $\begin{array}{l}\text { Glucuronide of } \\
\text { hydroxylated } \\
\text { metabolite }\end{array}$ & $\begin{array}{l}\text { - Monohydroxylated } \\
\text { metabolite at of } \\
\text { piperidine ring }\end{array}$ & $\begin{array}{l}\text { Feasel et al., } \\
2016\end{array}$ \\
\hline \multirow[t]{4}{*}{$\begin{array}{l}\text { Furanylfentanyl } \\
\text { (Fu-F) }\end{array}$} & In vitro & $\begin{array}{l}\text { Human } \\
\text { hepatocytes } \\
\text { Pooled } \\
\text { human } \\
\text { hepatocytes }\end{array}$ & 13 & $\begin{array}{l}\text { - Amide hydrolysis } \\
\text { - N-dealkylated } \\
\text { metabolite } \\
\text { - Dihydrodiol } \\
\text { metabolite at furan } \\
\text { group }\end{array}$ & & & $\begin{array}{l}\text { Watanabe } \\
\text { et al., } 2017\end{array}$ \\
\hline & In vivo & Urine (human) & 9 & $\begin{array}{l}\text { - Amide hydrolysis } \\
\text { - Dihydrodiol } \\
\text { metabolite at furan } \\
\text { group } \\
\text { - Dihydrodiol at furan } \\
\text { group and hydroxy at } \\
\text { ethyl linker } \\
\text { metabolite }\end{array}$ & $\begin{array}{l}\text { Glucuronide and } \\
\text { sulfate of } \\
\text { hydroxylated } \\
\text { metabolites }\end{array}$ & $\begin{array}{l}\text { - Dihydrodiol } \\
\text { metabolite at } \\
\text { furan group }\end{array}$ & \\
\hline & In vitro & $\begin{array}{l}\text { Human liver } \\
\text { microsomes }\end{array}$ & 17 & $\begin{array}{l}\text { - Despropnionyl } \\
\text { fentanyl } \\
\text { - Monohydroxylated } \\
\text { metabolite } \\
\text { - N-dealkylated } \\
\text { metabolite }\end{array}$ & & & $\begin{array}{l}\text { Gaulier et al., } \\
2017\end{array}$ \\
\hline & In vitro & $\begin{array}{l}\text { HepaRG cell } \\
\text { Line }\end{array}$ & 17 & $\begin{array}{l}\text { - Despropnionyl } \\
\text { fentanyl } \\
\text { - N-dealkylated } \\
\text { metabolite } \\
\text { - Dihydrodiol } \\
\text { metabolite (at furan } \\
\text { group) }\end{array}$ & $\begin{array}{l}\text { Glucuronide } \\
\text { hydroxylated } \\
\text { metabolite }\end{array}$ & & \\
\hline $\begin{array}{l}\text { 4-Fluoro- } \\
\text { isobutyrylfentanyl }\end{array}$ & In vitro & $\begin{array}{l}\text { Pooled } \\
\text { human } \\
\text { hepatocytes }\end{array}$ & 9 & $\begin{array}{l}\text { - N-dealkylated } \\
\text { metabolite of the } \\
\text { piperidine moiety } \\
\text { - Monohydroxy } \\
\text { metabolite at the } \\
\text { piperidine ring or at } \\
\text { the ethyl linker } \\
\text { - N-oxidation at the } \\
\text { piperidine ring }\end{array}$ & & & $\begin{array}{l}\text { Watanabe } \\
\text { et al., } 2017\end{array}$ \\
\hline
\end{tabular}


TABLE 3 | Continued

\begin{tabular}{|c|c|c|c|c|c|c|c|}
\hline Compound & $\begin{array}{l}\text { Study } \\
\text { type }\end{array}$ & $\begin{array}{l}\text { Matrix } \\
\text { (species) }\end{array}$ & $\begin{array}{l}\text { Total \# } \\
\text { phase I } \\
\text { metabolites }\end{array}$ & $\begin{array}{l}\text { Major metabolites } \\
\text { (decreasing order of } \\
\text { relative intensity) }\end{array}$ & $\begin{array}{l}\text { Phase II } \\
\text { metabolites }\end{array}$ & $\begin{array}{l}\text { Recommended } \\
\text { target analytes } \\
\text { in urine }\end{array}$ & References \\
\hline |sofentanyl & In vitro & Urine (rats) & 11 & $\begin{array}{l}\text { - N-dealkylation } \\
\text { followed by } \\
\text { hydroxylation of the } \\
\text { alkyl and aryl moiety } \\
\text { - Hydroxylation of the } \\
\text { propanamide side } \\
\text { chain followed by } \\
\text { oxidation to the } \\
\text { carboxylic acid } \\
\text { - Hydroxylation of the } \\
\text { benzyl moiety } \\
\text { followed by } \\
\text { methylation } \\
\text { - N-oxidation }\end{array}$ & $\begin{array}{l}\text { Glucuronides of } \\
\text { hydroxy } \\
\text { metabolites }\end{array}$ & $\begin{array}{l}\text { - N-dealkylated } \\
\text { metabolite }\end{array}$ & $\begin{array}{l}\text { Meyer et al., } \\
2012\end{array}$ \\
\hline 3-methylfentanyl & In vivo & Urine (rats) & $9 / 5$ & $\begin{array}{l}\text { - N-dealkylation } \\
\text { followed by } \\
\text { hydroxylation of the } \\
\text { alkyl and aryl moiety } \\
\text { - Hydroxylation of the } \\
\text { propanamide side } \\
\text { chain followed by } \\
\text { oxidation to the } \\
\text { carboxylic acid } \\
\text { - Hydroxylation of the } \\
\text { benzyl moiety } \\
\text { followed by } \\
\text { methylation }\end{array}$ & $\begin{array}{l}\text { Glucuronides of } \\
\text { hydroxy } \\
\text { metabolites }\end{array}$ & $\begin{array}{c}\text { - N-dealkylated } \\
\text { metabolite }\end{array}$ & $\begin{array}{l}\text { Meyer et al., } \\
2012\end{array}$ \\
\hline & In vivo & $\begin{array}{l}\text { - Blood } \\
\text { (human, } \\
n=1 \text { ) } \\
\text { - Bile } \\
\text { (human, } \\
n=1 \text { ) }\end{array}$ & 3 & $\begin{array}{l}\text { - O-desmethyl } \\
\text { metabolite } \\
\text { - Monohydroxylated } \\
\text { metabolite at } \\
\text { phenylethyl ring } \\
\text { - O-desmethyl } \\
\text { metabolite } \\
\text { hydroxylated at } \\
\text { phenylethyl ring }\end{array}$ & & $\begin{array}{l}\text { - O- } \\
\text { desmethylated- } \\
\text { metabolite }\end{array}$ & \\
\hline
\end{tabular}


TABLE 3 | Continued

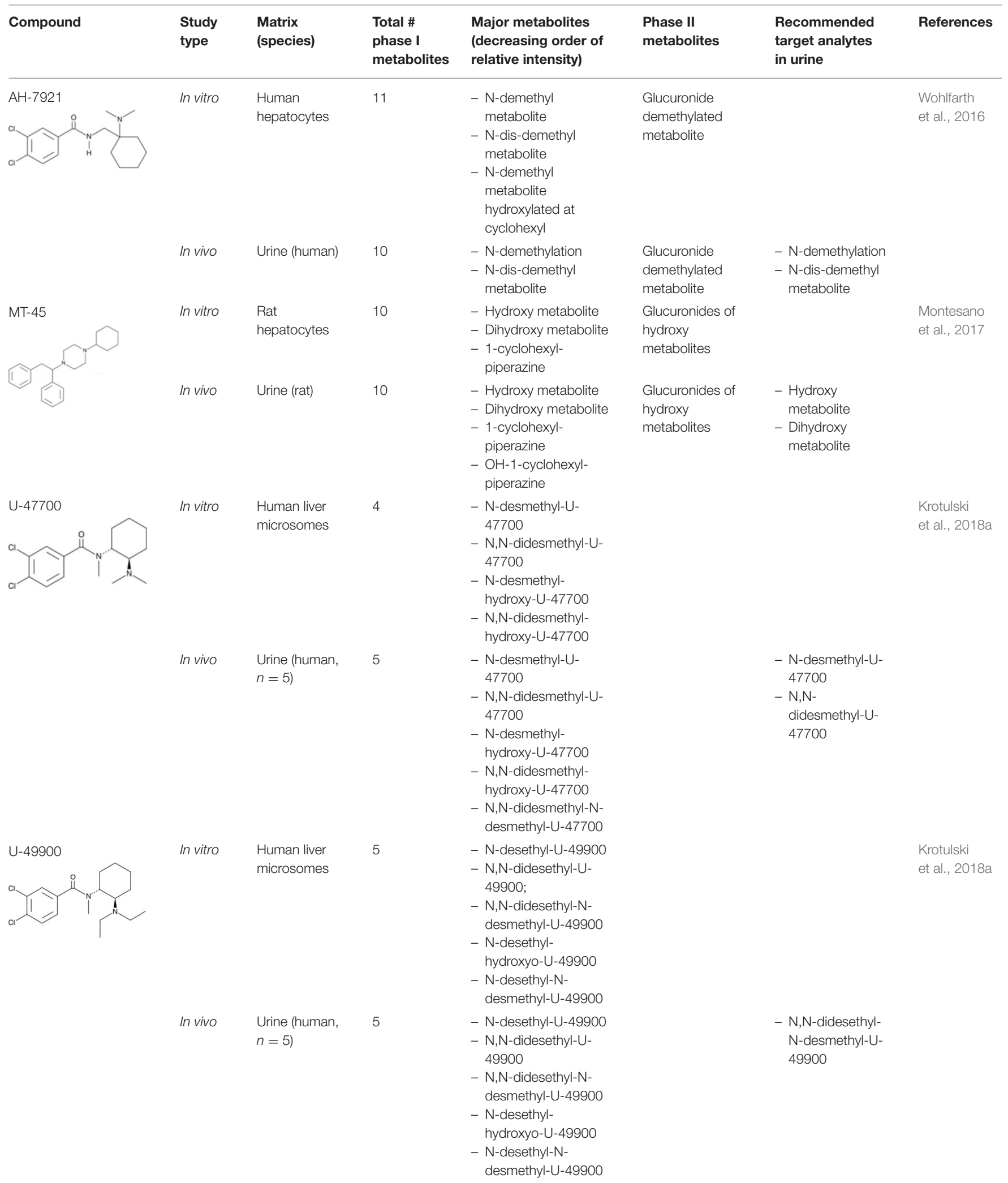


and N,N-Didesethyl-N-desmethyl-U-49900 was identified as the most abundant metabolite present. Unlike U-47700 specimens, U-49900 was detected in low abundance in urine samples (Krotulski et al., 2018a).

As indicated by Watanabe et al. (2017), the target metabolites should generally be abundant, specific of the parent drug, and prevalent in most, if not all, case samples. Given the strong structural similarities among emerging designer fentanyls, many of them are coincidentally biotransformed to the exact same metabolite. This fact can make identification of the specific parent drug in a case difficult. The ability to identify minor metabolites that are unique and specific to the parent drug is therefore of considerable importance. 4-ANPP can be formed by fentanyl and other different fentanyl analogs metabolism, and it is also a precursor contaminant found in seized illicit fentanyl and analogs, so its presence is not particularly diagnostic. Other common metabolites are: acetylnorfentanyl from acetyl-alpha-methylfentanyl or acetylfentanyl (Watanabe et al., 2017); norfentanyl from fentanyl, beta-hydroxythiofentanyl and alpha-methyl-fentanyl (Sato et al., 2010); norcarfentanil from carfentanil, sufentanil and remifentanil (Feasel et al., 2016). 3,4-dichloro-N-(2-aminocyclohexyl)-N-methyl-benzamide is a common metabolite of U-47700 and U-49900, but it is not a major metabolite in urine for either compound (Krotulski et al., 2018a).

Another important aspect of the metabolism is the identification of the enzymes involved. Pharmacokinetic interactions may be produced due to the presence of other substances metabolized by the same enzymes, ultimately affecting the drug blood concentrations. Fentanyl, sufentanyl and alfentanil are mainly metabolized by CYP 3A4 (Feierman and Lasker, 1996; Guitton et al., 1997). Steuer et al., identified CYP 3A4 and CYP 2D6 as the isoforms involved in the metabolism of butyrfentanyl (Steuer et al., 2017). Meyer et al., reported that CYP 3A4, CYP 3A5 and CYP 2C19 are involved in the metabolism of 3-methylfentanyl and isofentanyl and, in the case of isofentanyl, additionally CYP2D6 (Meyer et al., 2012). Remifentanil is the only family member of this class found to be $\sim 95 \%$ metabolized in the blood and tissues by non-CYP enzymes, probably due to an easily accessible ester group allowing rapid hydrolysis by circulating blood esterases (Bürkle et al., 1996).

\section{CONCENTRATIONS IN POSTMORTEM SPECIMENS AND OTHER FINDINGS}

The concentrations determined in postmortem specimens varied considerably depending on the type of synthetic opioid detected. Derivatives with potencies relative to morphine of more than 170 , showed concentrations in femoral blood in the low $\mathrm{ng} / \mathrm{mL}$ or $\mathrm{pg} / \mathrm{mL}$ range, while those derivatives with potencies similar to morphine showed concentrations of hundreds, and even thousands, of $\mathrm{ng} / \mathrm{mL}$. An exception happens with furanyl fentanyl, which is seven times more potent than morphine (Higashikawa and Suzuki, 2008), but the reported femoral concentrations were less than $50 \mathrm{ng} / \mathrm{mL}$. Typical morphine postmortem concentrations in blood in fatalities are from 200 to $2,300 \mathrm{ng} / \mathrm{mL}$, for methadone 400 to $1,800 \mathrm{ng} / \mathrm{mL}$, for buprenorphine $1.1-29 \mathrm{ng} / \mathrm{mL}$ and norbuprenorphine (active metabolite) $0.2-13 \mathrm{ng} / \mathrm{mL}$ (Baselt, 2017), and for oxymorphone 23-554 ng/mL (Crum et al., 2013). The potency of the different drugs affects their lethal levels, but other important issues, such as the presence of other CNS depressant drugs, and developed opioids tolerance, have to be taken into account in the interpretation of the concentrations. The derivative with the highest number of published cases was acrylfetanyl, and with the lowest MT-45. Table 4 summarizes the concentrations of the parent drugs found in case reports and articles where overdose due to a specific opioid was the cause of death.

In several cases, multiple synthetic opioids were detected. Acetylfentanyl and fentanyl were frequently found together (Pearson et al., 2015; Poklis et al., 2015; Dwyer et al., 2018). Other combinations were butyryl fentanyl and acetyl fentanyl (McIntyre et al., 2016b; Poklis et al., 2016), or U-47700 (Mohr et al., 2016); furanyl fentanyl and acetyl fentanyl (Papsun et al., 2017), acryl fentanyl (Butler et al., 2017), butyryl fentanyl (Mohr et al., 2016), fentanyl (Guerrieri et al., 2017a), or carfentanil (Shanks and Behonick, 2017); carfentanil and fentanyl (Shanks and Behonick, 2017); and tetrahydrofuran fentanyl and U-49900 (Krotulski et al., 2018b). The femoral concentrations reported in those combination cases were frequently below the range of the concentrations summarized in Table 4. Acetylfentanyl median and concentration range in multiple synthetic opioids cases were 9.4, $0.4-240 \mathrm{ng} / \mathrm{mL}(n=15)$; acrylfentanyl $0.3 \mathrm{ng} / \mathrm{mL}(n=1)$; butyrfentanyl 14.9, $0.3-58 \mathrm{ng} / \mathrm{mL}(n=4)$; carfentanil 0.08, $0.05-$ $0.1 \mathrm{ng} / \mathrm{mL}(n=2)$; fentanyl $8.2,1.1-38 \mathrm{ng} / \mathrm{mL}(n=14)$; furanyl fentanyl $1.7,0.6-6.1 \mathrm{ng} / \mathrm{mL}(n=4)$ and $\mathrm{U}-4770017 \mathrm{ng} / \mathrm{mL}$ $(n=1)$.

In all of the reports mentioned in Table 4 and above, synthetic opioids were commonly detected with other drugs, especially other CNS depressants, such as benzodiazepines, ethanol and other opioids. This combination may produce a pharmacodynamic interactions and increase the risk of respiratory depression. This possible interaction between opioids, alcohol and benzodiazepines has been previously described for other opioids, such as buprenorphine (Häkkinen et al., 2012; Seldén et al., 2012), methadone (Jones et al., 2012; Pilgrim et al., 2013; Nielsen et al., 2015), oxycodone (Ogle et al., 2012), and heroin (Thaulow et al., 2014). Among the reviewed cases positive for synthetic opioids other than fentanyl, 44 reported as cause of death intoxication due to multiple drugs and 77 intoxication mainly due to one specific opioid. The manner of death was predominantly accidental $(n=99)$, and suicides were reported in 7 cases.

\section{POSTMORTEM REDISTRIBUTION AND STABILITY}

Postmortem changes in drug concentrations can happen via postmortem redistribution (PMR) from tissues of a higher to a lower concentration. Physicochemical and pharmacological properties of the analytes, such as $\mathrm{pKa}, \log \mathrm{P}$, volume of 
TABLE 4 | Postmortem concentrations in different biological samples for synthetic opioids (median, range, number of cases).

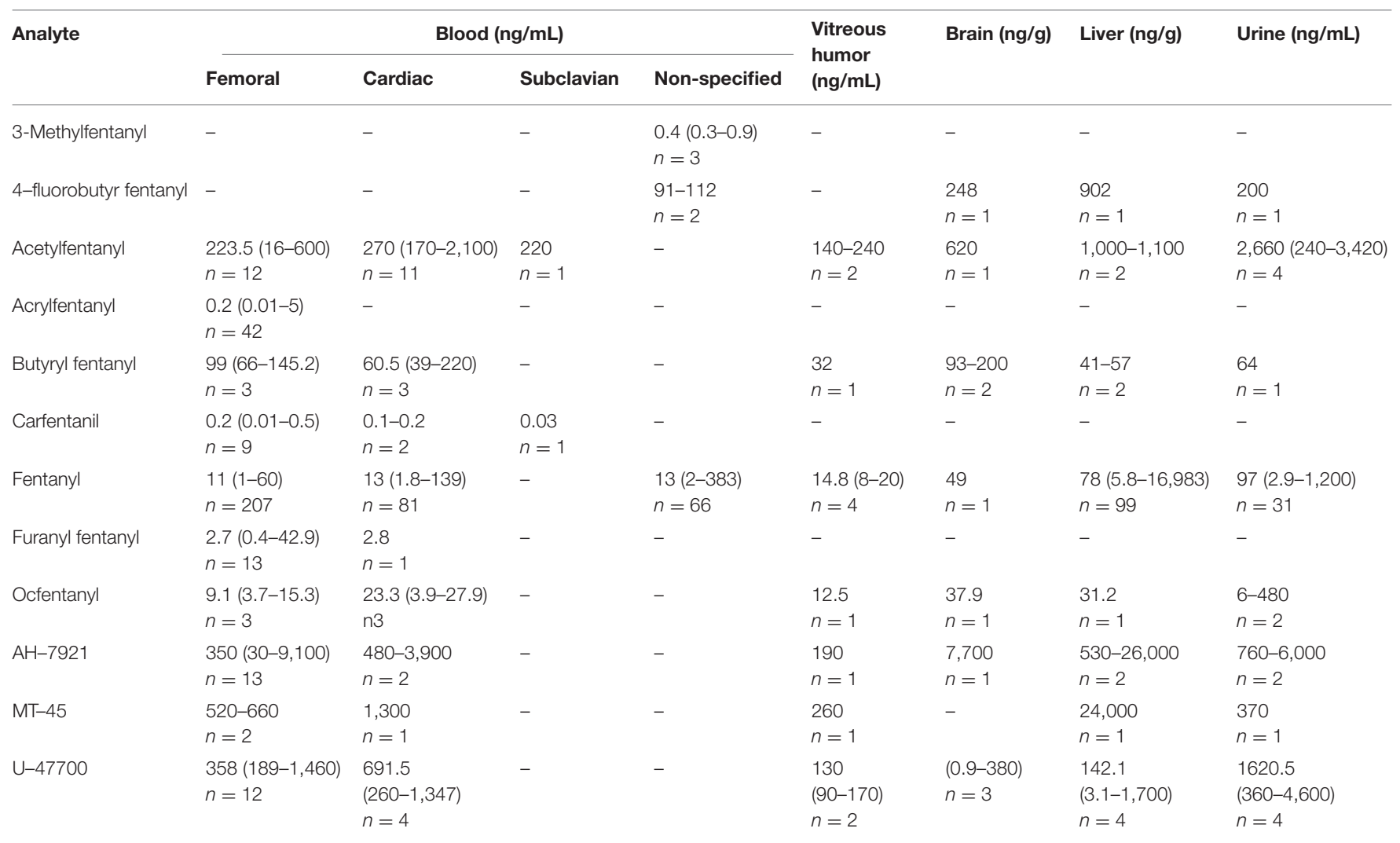

3-Methylfentanyl references: (Ojanperä et al., 2006).

4-fluorobutyr fentanyl references: (Rojkiewicz et al., 2017).

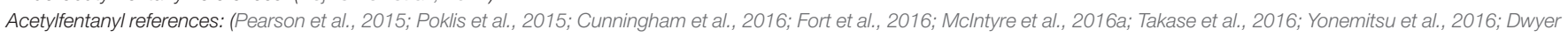
et al., 2018).

Acrylfentanyl references: (Butler et al., 2017; Guerrieri et al., 2017b).

Butyryl fentanyl references: (Poklis et al., 2016; Staeheli et al., 2016).

Carfentanil references: (Shanks and Behonick, 2017; Swanson et al., 2017; Hikin et al., 2018).

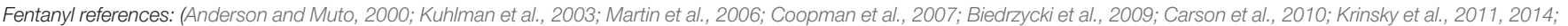

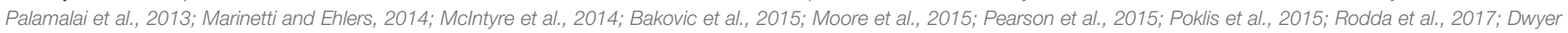
et al., 2018).

Furanyl fentanyl references: (Mohr et al., 2016; Guerrieri et al., 2017a; Martucci et al., 2017; Papsun et al., 2017).

Ocfentanyl references: (Coopman et al., 2016; Dussy et al., 2016; Allibe et al., 2018).

AH-7921 references: (Karinen et al., 2014; Kronstrand et al., 2014; Vorce et al., 2014; Fels et al., 2017).

MT-45 references: (Papsun et al., 2016; Fels et al., 2017).

U-47700 references: (Elliott et al., 2016; Mohr et al., 2016; Dziadosz et al., 2017; Papsun et al., 2017; Rohrig et al., 2017).

distribution (Vd) and protein binding, may indicate drugs that experience this postmortem phenomenon. Lipophilic basic drugs with a $\mathrm{Vd}>3 \mathrm{~L} / \mathrm{kg}$, such as fentanyl, may undergo PMR. Fentanyl has been reported to undergo extensive PMR (Luckenbill et al., 2008; Olson et al., 2010; Palamalai et al., 2013; Brockbals et al., 2018). In the case of the synthetic opioids, limited data is currently available about PMR, and as well as information about pKa, log $\mathrm{P}$ and Vd (Tables 2, 3). Staeheli et al. (2016) reported postmortem concentration changes of butyrfentanyl and metabolites, suggesting these compounds were prone to PMR. PMR reports about other synthetic opioids are not currently available.

Based on currently published case reports and articles, the cardiac blood-to-femoral blood and liver-to-femoral blood ratios were calculated to predict candidates of PMR. Results are summarized in Table 5. Due to the scarce amount of data available (1-4 cases per analyte), no conclusions could be drawn. Synthetic opioids showed median cardiac-to-femoral ratios around 1 , and a tendency to accumulate in the liver. Regarding the distribution to vitreous humor, it may be slow showing higher concentrations in blood. Other factors, such as time of death and sample collection, or rapid vs. delayed deaths, has not been taken into account in this analysis due to the limited data available.

PMR is still a controversial issue for classic opioids. Hargrove and Molina (2014) showed insignificant redistribution of morphine from central sites within $24 \mathrm{~h}$ after death in bodies kept at $4^{\circ} \mathrm{C}$, while Staeheli et al. (2017) observed a significant increase of morphine concentration, although these changes were not relevant for forensic interpretation. 
TABLE 5 | Postmortem concentration ratios in different biological samples for synthetic opioids (median, range, number of cases).

\begin{tabular}{|c|c|c|c|c|}
\hline Analyte & $\begin{array}{l}\text { Cardiac-to- } \\
\text { femoral }\end{array}$ & Liver-to-femoral & $\begin{array}{l}\text { Vitreous humor- } \\
\text { to-femoral }\end{array}$ & References \\
\hline Acetylfentanyl & $\begin{array}{l}1.2(0.8-1.6) \\
n=4\end{array}$ & $\begin{array}{l}3.8-5.7 \\
n=2\end{array}$ & $\begin{array}{l}0.6-0.9 \\
n=2\end{array}$ & $\begin{array}{l}\text { Cunningham et al., 2016; } \\
\text { Fort et al., 2016; Mclntyre } \\
\text { et al., 2016a; Yonemitsu } \\
\text { et al., } 2016\end{array}$ \\
\hline Butyryl fentanyl & $\begin{array}{l}0.6(0.4-2.2) \\
n=3\end{array}$ & $\begin{array}{l}0.4-0.9 \\
n=2\end{array}$ & $\begin{array}{l}0.3 \\
n=1\end{array}$ & $\begin{array}{l}\text { Poklis et al., 2016; Staeheli } \\
\text { et al., } 2016\end{array}$ \\
\hline Fentanyl & $(0.7-4.6) n=54$ & $\begin{array}{l}6.6(1.4-539.4) \\
n=75\end{array}$ & $\begin{array}{l}1.5(1.1-1.8) \\
n=3\end{array}$ & $\begin{array}{l}\text { Anderson and Muto, 2000; } \\
\text { Krinsky et al., 2011, 2014; } \\
\text { Palamalai et al., 2013; } \\
\text { Mclntyre et al., 2014; } \\
\text { Bakovic et al., } 2015\end{array}$ \\
\hline Furanyl fentanyl & $\begin{array}{l}1.5 \\
n=1\end{array}$ & - & - & Martucci et al., 2017 \\
\hline Ocfentanyl & $\begin{array}{l}1.5(1.1-3.1) \\
n=3\end{array}$ & $\begin{array}{l}2 \\
n=1\end{array}$ & $\begin{array}{l}0.8 \\
n=1\end{array}$ & $\begin{array}{l}\text { Coopman et al., 2016; } \\
\text { Dussy et al., 2016; Allibe } \\
\text { et al., } 2018\end{array}$ \\
\hline $\mathrm{AH}-7921$ & $\begin{array}{l}0.4-1.1 \\
n=2\end{array}$ & $\begin{array}{l}1.2-2.9 \\
n=2\end{array}$ & $\begin{array}{l}0.4 \\
n=1\end{array}$ & $\begin{array}{l}\text { Vorce et al., 2014; Fels } \\
\text { et al., } 2017\end{array}$ \\
\hline MT-45 & $\begin{array}{l}2 \\
n=1\end{array}$ & $\begin{array}{l}36.4 \\
n=1\end{array}$ & $\begin{array}{l}0.4 \\
n=1\end{array}$ & Fels et al., 2017 \\
\hline U-47700 & $\begin{array}{l}1.5(0.7-2.6) \\
n=4\end{array}$ & $\begin{array}{l}0.4(0.003-8.9) \\
n=4\end{array}$ & $\begin{array}{l}0.2-0.9 \\
n=2\end{array}$ & $\begin{array}{l}\text { Dziadosz et al., 2017; } \\
\text { Rohrig et al., } 2017\end{array}$ \\
\hline
\end{tabular}

Morphine-derivatives, such us hydrocodone (Saitman et al., 2015), codeine (Frost et al., 2016), and oxycodone (Brockbals et al., 2018), are unlikely to undergo substantial PMR changes. More lipophilic opioids with higher Vd, like methadone (Jantos and Skopp, 2013; Holm and Linnet, 2015; Brockbals et al., 2018), may undergo PMR.

Several studies have been conducted to evaluate stability of fentanyl and some of its derivatives in fortified biological samples, such as blood, plasma and urine. Eleven fentanils (fentanyl, norfentanyl, carfentanil, norcarfentanil, sufentanil, norsufentanil, lofentanil, 3-methylfentanyl, alfa-methylfentanyl, ohmefentanyl, and remifentanil acid metabolite), were stable in urine samples stored at $-20^{\circ} \mathrm{C}$ or below for at least 2 months. However, remifentanil in urine samples decreased by approximately $90 \%$ within 1 week at room temperature and by more than $50 \%$ in samples stored for 1 week at $4^{\circ} \mathrm{C}$. Because of the instability of that analyte, the authors recommended to analyze the primary metabolite, remifentanil acid (Wang and Bernert, 2006). Fentanyl and its metabolites norfentanyl, despropionylfentanyl and hydroxynorfentanyl were stable in urine after 3 freeze-thaw cycles, and after storage at $-20^{\circ} \mathrm{C}$ for 2 months (Mahlke et al., 2014).

Fentanyl, norfentanyl, acetyl fentanyl and acetyl norfentanyl spiked into whole blood were stable after three freeze-thaw cycles and at room temperature for $72 \mathrm{~h}$ (Poklis et al., 2015). No loss of fentanyl concentration could be observed after 3 months of storage at $4-8^{\circ} \mathrm{C}$ and $-20^{\circ} \mathrm{C}$ in blood samples at 5 and $10 \mathrm{ng} / \mathrm{mL}$ (Andresen et al., 2012). However, another study showed fentanyl and its metabolites norfentanyl, despropionylfentanyl and hydroxynorfentanyl lose up to $51.6 \%$ after 3 freeze-thaw cycles, and fentanyl and despropionylfentanyl up to $34.8 \%$ after storage at $-20^{\circ} \mathrm{C}$ for 2 months (Mahlke et al., 2014). Furanylfentanyl showed no significant degradation in blood samples at 5 and $10 \mathrm{ng} / \mathrm{mL} 48 \mathrm{~h}$ room temp and at $4{ }^{\circ} \mathrm{C} 7$ days (Guerrieri et al., 2017a) and up to 30 days (Mohr et al., 2016).

Regarding the new synthetic opioids not related to fentanyl, U-47700 was stable in blood refrigerated for up to 30 days (Mohr et al., 2016). AH-7921 was found to be stable for at least 21 days in blood and plasma at room temperature (Soh and Elliot, 2014). In the case of MT-45, a loss of 50\% was observed after 12 months of storage (Papsun et al., 2016). Further studies are necessary to evaluate the stability of the different synthetic opioids and metabolites, and in additional biological samples of forensic interest, such as vitreous humor and tissues.

\section{CONCLUSION}

We performed a critical review of the currently available literature to assist in the toxicological interpretation of synthetic opioids postmortem cases. Synthetic opioids constitute a heterogenous group of compounds related or not to fentanyl, mostly basic and lipophilic, with a wide range of potencies related to morphine, from 1 to 10,000. Research has been conducted in the investigation of metabolic pathways and identification of target metabolites of fentanyl derivatives and non-structurally related synthetic opioids, showing similarities 
and differences from fentanyl depending on the compound. Postmortem concentrations seemed to correlate with their potency, although the presence of other CNS depressants, such as ethanol and benzodiazepines has to be taken into account. Further research is guaranteed to investigate postmortem redistribution phenomena of this class of compounds, and stability issues in postmortem samples.

\section{REFERENCES}

Al-Asmari, A. I., Anderson, R. A., and Cooper, G. A. (2009). Oxycodonerelated fatalities in the west of Scotland. J. Anal. Toxicol. 33, 423-432. doi: $10.1093 /$ jat/33.8.423

Allibe, N., Richeval, C., Phanithavong, M., Faure, A., Allorge, D., Paysant, F., et al. (2018). Fatality involving ocfentanil documented by identification of metabolites. Drug Test. Anal. 10, 995-1000. doi: 10.1002/dta.2326

Anderson, D. T., and Muto, J. J. (2000). Duragesic transdermal patch: postmortem tissue distribution of fentanyl in 25 cases. J. Anal. Toxicol. 24, 627-634. doi: $10.1093 /$ jat/24.7.627

Andresen, H., Gullans, A., Veselinovic, M., Anders, S., Schmoldt, A., IwersenBergmann, S., et al. (2012). Fentanyl: toxic or therapeutic? postmortem and antemortem blood concentrations after transdermal fentanyl application. $J$. Anal. Toxicol. 36, 182-194. doi: 10.1093/jat/bks005

Armenian, P., Vo, K. T., Barr-Walker, J., and Lynch, K. L. (2018). Fentanyl, fentanyl analogs and novel synthetic opioids: a comprehensive review. Neuropharmacology 134, 121-132. doi: 10.1016/j.neuropharm.2017.10.016

Bakovic, M., Nestic, M., and Mayer, D. (2015). Death by band-aid_ fatal misuse of transdermal fentanyl patch. Int. J. Legal Med. 129, 1247-1252. doi: 10.1007/s00414-015-1209-z

Baselt, R. C. (2017). Disposition of Toxic Drugs and Chemicals in Man, 11th Edn. Seal Beach, CA: Biomedical Pubns.

Biedrzycki, O. J., Bevan, D., and Lucas, S. (2009). Fatal overdose due to prescription fentanyl patches in a patient with sickle cell/ $\beta$-thalassemia and acute chest syndrome: a case report and review of the literature. Am. J. Forensic Med. Pathol. 30, 188-190. doi: 10.1097/PAF.0b013e318187de71

Brittain, R. T., Jack, D., and Tyers, M. B. (1977). Pharmacological and certain chemical properties of AH 10407, an unusually short-acting, competitive neuromuscular blocking drug, and some related compounds. Br. J. Pharmacol. 61, 47-55.

Brockbals, L., Staeheli, S. N., Gascho, D., Ebert, L. C., Kraemer, T., and Steuer, A. E. (2018). Time-dependent postmortem redistribution of opioids in blood and alternative matrices. J. Anal. Toxicol. 42, 365-374. doi: 10.1093/jat/bky017

Bruera, E., Pereira, J., Watanabe, S., Belzile, M., Kuehn, N., and Hanson, J. (1996). Opioid rotation in patients with cancer pain. Cancer 78, 852-857. doi: 10.1002/ (SICI) 1097-0142(19960815)78:4<852::AID-CNCR23>3.0.CO;2-T

Bürkle, H., Dunbar, S., and Van Aken, H. (1996). Remifentanil: a novel, short-acting, Mu-opioid. Anesth. Analg. 83, 646-651. doi: 10.1213/00000539-199609000-00038

Butler, D. C., Shanks, K., Behonick, G. S., Smith, D., Presnell, S. E., and Tormos, L. M. (2017). Three cases of fatal acrylfentanyl toxicity in the united states and a review of literature. J. Anal. Toxicol. 42, e6-e11. doi: 10.1093/jat/bkx083

Carson, H. J., Knight, L. D., Dudley, M. H., and Garg, U. (2010). A fatality involving an unusual route of fentanyl delivery: chewing and aspirating the transdermal patch. Leg. Med. 12, 157-159. doi: 10.1016/j.legalmed.2010.03.001

Cheney, B. V., Szmuszkovicz, J., Lahti, R. A., and Zichi, D. A. (1985). Factors affecting binding of trans-N-[2-(Methylamino)cyclohexyl]benzamides at the primary morphine receptor. J. Med. Chem. 28, 1853-1864. doi: 10.1021/jm00150a017

Christoph, T., Kögel, B., Strassburger, W., and Schug, S. A. (2007). Tramadol has a better potency ratio relative to morphine in neuropathic than in nociceptive pain models. Drugs R D 8, 51-57. doi: 10.2165/00126839-200708010-00005

Cicero, T. J., Ellis, M. S., and Kasper, Z. A. (2017). Increased use of heroin as an initiating opioid of abuse. Addict. Behav. 74, 63-66. doi: 10.1016/j.addbeh.2017.05.030

\section{AUTHOR CONTRIBUTIONS}

MC and GC contributed conception and design of the review. MC, RC, and JP searched, organized, reviewed and analyzed the case reports and research articles. MC wrote the first draft of the manuscript. All authors contributed to manuscript revision, read and approved the submitted version.

Coopman, V., and Cordonnier, J. (2017). 'Spice-like' herbal incense laced with the synthetic opioid U-47700. Toxicol. Anal. Clin. 30, 75-79. doi: 10.1016/j.toxac.2017.07.004

Coopman, V., Cordonnier, J., De Leeuw, M., and Cirimele, V. (2016). Ocfentanil overdose fatality in the recreational drug scene. Forensic Sci. Int. 266, 469-473. doi: 10.1016/j.forsciint.2016.07.005

Coopman, V., Cordonnier, J., Pien, K., and Van Varenbergh, D. (2007). LC-MS/MS analysis of fentanyl and norfentanyl in a fatality due to application of multiple durogesic $($ ) transdermal therapeutic systems. Forensic Sci. Int. 169, 223-27. doi: 10.1016/j.forsciint.2006.03.018

Crum, E. D., Bailey, K. M., Richards-Waugh, L. L., Clay, D. J., Gebhardt, M. A., and Kraner, J. C. (2013). Validation of blood and liver oxymorphone analysis using LC-MS-MS: concentrations in 30 fatal overdoses. J. Anal. Toxicol. 37, 512-516. doi: 10.1093/jat/bkt077

Cunningham, S. M., Haikal, N. A., and Kraner, J. C. (2016). Fatal intoxication with acetyl fentanyl. J. Forensic Sci. 61, 276-280. doi: 10.1111/1556-4029.12953

Dahan, A., Yassen, A., Bijl, H., Romberg, R., Sarton, E., Teppema, L., et al. (2005). Comparison of the respiratory effects of intravenous buprenorphine and fentanyl in humans and rats. Br. J. Anaesth. 94, 825-34. doi: 10.1093/bja/aei145

Drug Enforcement Administration, Department of Justice (2018). Schedules of Controlled substances: temporary placement of fentanyl related substances in schedule I. Fed. Reg. 83, 5188-5192.

Drummer, O. (2018). Fatalities caused by novel opioids: a review. Forensic Sci. Res. doi: 10.1080/20961790.2018.1460063. [Epub ahead of print].

Dussy, F. E., Hangartner, S., Hamberg, C., Berchtold, C., Scherer, U., Schlotterbeck, G., et al. (2016). An acute ocfentanil fatality: a case report with postmortem concentrations. J. Anal. Toxicol. 40, 761-766. doi: 10.1093/jat/bkw096

Dwyer, J. B., Janssen, J., Luckasevic, T. M., and Williams, K. E. (2018). Report of increasing overdose deaths that include acetyl fentanyl in multiple counties of the southwestern region of the commonwealth of Pennsylvania in 2015-2016. J. Forensic Sci. 63, 195-200. doi: 10.1111/1556-4029.13517

Dziadosz, M., Klintschar, M., and Teske, J. (2017). Postmortem concentration distribution in fatal cases involving the synthetic opioid U-47700. Int. J. Legal Med. 131, 1555-1556. doi: 10.1007/s00414-017-1593-7

Elliott, S. P., Brandt, S. D., and Smith, C. (2016). The first reported fatality associated with the synthetic opioid 3,4-Dichloro-N-[2(Dimethylamino)Cyclohexyl]-N-Methylbenzamide (U-47700) and implications for forensic analysis. Drug Test. Anal. 8, 875-879. doi: $10.1002 / \mathrm{dta} .1984$

EMCDDA (2015). Report on the risk assessment of MT-45 in the framework of the Council Decision on new psychoactive substances. Luxembourg: Publications Office of the European Union. Available online at: http://www.emcdda.europa. eu/publications/risk-assessments/mt-45_en

Feasel, M. G., Wohlfarth, A., Nilles, J. M., Pang, S., Kristovich, R. L., and Huestis, M. A. (2016). Metabolism of carfentanil, an ultra-potent opioid, in human liver microsomes and human hepatocytes by high-resolution mass spectrometry. AAPS J. 18, 1489-1499. doi: 10.1208/s12248-0169963-5

Feierman, D. E., and Lasker, J. M. (1996). Metabolism of fentanyl, a synthetic opioid analgesic, by human liver microsomes. Role of CYP3A4. Drug Metab. Disp. 24, 932-939.

Fels, H., Krueger, J., Sachs, H., Musshoff, F., Graw, M., Roider, G., et al. (2017). Two fatalities associated with synthetic opioids: AH-7921 and MT-45. Forensic Sci. Int. 277, e30-e35. doi: 10.1016/j.forsciint.2017.04.003

Fort, C., Curtis, B., Nichols, C., and Niblo, C. (2016). Acetyl fentanyl toxicity: two case reports. J. Anal. Toxicol. 40, 754-757. doi: 10.1093/jat/bkw068 
Frost, J., Løkken, T. N., Helland, A., Nordrum, I. S., and Slørdal, L. (2016). Post-mortem levels and tissue distribution of codeine, codeine6-glucuronide, norcodeine, morphine and morphine glucuronides in a series of codeine-related deaths. Forensic Sci. Int. 262, 128-137. doi: 10.1016/j.forsciint.2016.02.051

Gaulier, J.-M., Richeval, C., Gicquel, T., Hugbart, C., Le Dare, B., Allorge, D., et al. (2017). In vitro characterization of nps metabolites produced by human liver microsomes and the hepaRG cell line using liquid chromatography-high resolution mass spectrometry (LC-HRMS) analysis: application to furanyl fentanyl. Curr. Pharm. Biotechnol. 18, 806-814. doi: $10.2174 / 1389201018666171122124401$

Goggin, M. M., Nguyen, A., and Janis, G. C. (2017). Identification of unique metabolites of the designer opioid furanyl fentanyl. J. Anal. Toxicol. 41, 367-375. doi: 10.1093/jat/bkx022

Goromaru, T., Matsuura, H., Yoshimura, N., Miyawaki, T., Sameshima, T., Miyao, J., et al. (1984). Identification and quantitative determination of fentanyl metabolites in patients by gas chromatography-mass spectrometry. Anesthesiology 61, 73-77. doi: 10.1097/00000542-198407000-00013

Guerrieri, D., Rapp, E., Roman, M., Druid, H., and Kronstrand, R. (2017a). Postmortem and toxicological findings in a series of furanylfentanyl-related deaths. J. Anal. Toxicol. 41, 242-249. doi: 10.1093/jat/bkw129

Guerrieri, D., Rapp, E., Roman, M., Thelander, G., and Kronstrand, R. (2017b). Acrylfentanyl: another new psychoactive drug with fatal consequences. Forensic Sci. Int. 277, e21-e29. doi: 10.1016/j.forsciint.2017.05.010

Guitton, J., Desage, M., Alamercery, S., Dutruch, L., Dautraix, S., Perdrix, J. P., et al. (1997). Gas chromatographic - mass spectrometry and gas chromatographic - fourier transform infrared spectroscopy assay for the simultaneous identification of fentanyl metabolites. J. Chromatogr. B 59, 59-70. doi: 10.1016/S0378-4347(97)00050-9

Häkkinen, M., Launiainen, T., Vuori, E., and Ojanperä, I. (2012). Benzodiazepines and alcohol are associated with cases of fatal buprenorphine poisoning. Eur. J. Clin. Pharmacol. 68, 301-309. doi: 10.1007/s00228-011-1122-4

Hargrove, V. M., and Molina, D. K. (2014). Peripheral postmortem redistribution of morphine. Am. J. Forensic Med. Pathol. 35, 106-108. doi: 10.1097/PAF.0000000000000044

Hayes, A. G., and Tyers, M. B. (1983). Determination of receptors that mediate opiate side effects in the mouse. Br. J. Pharmacol. 79, 731-736. doi: 10.1111/j.1476-5381.1983.tb10011.x

Higashikawa, Y., and Suzuki, S. (2008). Studies on 1-(2-Phenethyl)-4-(NPropionylanilino)Piperidine (Fentanyl) and its related compounds. VI. structure-analgesic activity relationship for fentanyl, methylsubstituted fentanyls and other analogues. Forensic Toxicol. 26, 1-5. doi: 10.1007/s11419-007-0039-1

Hikin, L., Smith, P. R., Ringland, E., Hudson, S., and Morley, S. R. (2018). Multiple fatalities in the north of england associated with synthetic fentanyl analogue exposure: detection and quantitation a case series from early 2017. Forensic Sci. Int. 282, 179-183. doi: 10.1016/j.forsciint.2017.11.036

Holm, K. M., and Linnet, K. (2015). Distribution of enantiomers of methadone and its main metabolite eddp in human tissues and blood of postmortem cases. J. Forensic Sci. 60, 95-101. doi: 10.1111/1556-4029.12627

Jantos, R., and Skopp, G. (2013). Postmortem blood and tissue concentrations of $\mathrm{R}$ - and S-enantiomers of methadone and its metabolite EDDP. Forensic Sci. Int. 226, 254-60. doi: 10.1016/j.forsciint.2013.01.038

Jones, A. W., Holmgren, A., and Ahlner, J. (2012). Blood methadone concentrations in living and deceased persons: variations over time, subject demographics, and relevance of coingested drugs. J. Anal. Toxicol. 36, 12-18. doi: $10.1093 /$ jat $/$ bkr013

Jumbelic, M. I. (2010). Deaths with transdermal fentanyl patches. Am. J. Forensic Med. Pathol. 31, 18-21. doi: 10.1097/PAF.0b013e31818738b8

Kanamori, T., Togawa Iwata, Y., Segawa, H., Yamamuro, T., Kuwayama, K., Tsujikawa, K., et al. (2018). Metabolism of fentanyl and acetylfentanyl in human-induced pluripotent stem cell-derived hepatocytes. Biol. Pharm. Bull. 41, 106-114. doi: 10.1248/bpb.b17-00709

Karinen, R., Tuv, S. S., Rogde, S., Peres, M. D., Johansen, U., Frost, J., et al. (2014). Lethal poisonings with AH-7921 in combination with other substances. Forensic Sci. Int. 244, e21-e24. doi: 10.1016/j.forsciint.2014. 08.013
Krinsky, C. S., Lathrop, S. L., Crossey, M., Baker, G., and Zumwalt, R. (2011). A toxicology-based review of fentanyl-related deaths in new mexico (1986-2007). Am. J. Forensic Med. Pathol. 32, 347-351. doi: 10.1097/PAF.0b013e31822ad269

Krinsky, C. S., Lathrop, S. L., and Zumwalt, R. (2014). An examination of the postmortem redistribution of fentanyl and interlaboratory variability. $J$. Forensic Sci. 59, 1275-1279. doi: 10.1111/1556-4029.12381

Kronstrand, R., Thelander, G., Lindstedt, D., Roman, M., and Kugelberg, F. C. (2014). Fatal intoxications associated with the designer opioid AH-7921. J. Anal. Toxicol. 38, 599-604. doi: 10.1093/jat/bku057

Krotulski, A. J., Mohr, A. L. A., Papsun, D. M., and Logan, B. K. (2018a). Metabolism of novel opioid agonists U-47700 and U-49900 using human liver microsomes with confirmation in authentic urine specimens from drug users. Drug Test. Anal. 10, 127-136. doi: 10.1002/dta.2228

Krotulski, A. J., Papsun, D. M., Friscia, M., Swartz, J. L., Holsey, B. D., and Logan, B. K. (2018b). Fatality following ingestion of tetrahydrofuranylfentanyl, U-49900 and Methoxy-Phencyclidine. J. Anal. Toxicol. 42, e27-32. doi: $10.1093 /$ jat/bkx092

Kuhlman, J. J., McCaulley, R., Valouch, T. J., and Behonick, G. S. (2003). Fentanyl use, misuse, and abuse: a summary of 23 postmortem cases. J. Anal. Toxicol. 27, 499-504. doi: 10.1093/jat/27.7.499

Liu, L., Wheeler, S. E., Venkataramanan, R., Rymer, J. A., Pizon, A. F., Lynch, M. J., et al. (2018). Newly emerging drugs of abuse and their detection methods. Am. J. Clin. Pathol. 149, 105-116. doi: 10.1093/ajcp/aqx138

Luckenbill, K., Thompson, J., Middleton, O., Kloss, J., and Apple, F. (2008). Fentanyl postmortem redistribution: preliminary findings regarding the relationship among femoral blood and liver and heart tissue concentrations. J. Anal. Toxicol. 32, 639-643. doi: 10.1093/jat/32.8.639

Mahlke, N. S., Ziesenitz, V., Mikus, G., and Skopp, G. (2014). Quantitative lowvolume assay for simultaneous determination of fentanyl, norfentanyl, and minor metabolites in human plasma and urine by liquid chromatographytandem mass spectrometry (LC-MS/MS). Int. J. Legal Med. 128, 771-778. doi: $10.1007 / \mathrm{s} 00414-014-1040-y$

Marchei, E., Pacifici, R., Mannocchi, G., Marinelli, E., Busard,ò, F. P., and Pichini, S. (2018). New synthetic opioids in biological and non-biological matrices: a review of current analytical methods. Trends Anal. Chem. 102, 1-15. doi: 10.1016/j.trac.2018.01.007

Marinetti, L. J., and Ehlers, B. J. (2014). A series of forensic toxicology and drug seizure cases involving illicit fentanyl alone and in combination with heroin, cocaine or heroin and cocaine. J. Anal. Toxicol. 38, 592-598. doi: 10.1093 /jat/bku086

Martin, T. L., Woodall, K. L., and McLellan, B. A. (2006). Fentanyl-related deaths in ontario, canada: toxicological findings and circumstances of death in 112 cases (2002-2004). J. Anal. Toxicol. 30, 603-610. doi: 10.1093/jat/30.8.603

Martucci, H. F. H., Ingle, E. A., Hunter, M. D., and Rodda, L. N. (2017). Distribution of furanyl fentanyl and 4-ANPP in an accidental acute death: a case report. Forensic Sci. Int. 283, e13-e17. doi: 10.1016/j.forsciint.2017.12.005

McClain, D. A., and Hug, C. C. (1980). Intravenous fentanyl kinetics. Clin. Pharmacol. Ther. 28, 106-114. doi: 10.1038/clpt.1980.138

McIntyre, I. M., Gary, R. D., Estrada, J., and Nelson, C. L. (2014). Antemortem and postmortem fentanyl concentrations: a case report. Int. J. Legal Med. 128 , 65-67. doi: 10.1007/s00414-013-0897-5

McIntyre, I. M., Trochta, A., Gary, R. D., Malamatos, M., and Lucas, J. R. (2016a). An acute acetyl fentanyl fatality: a case report with postmortem concentrations. J. Anal. Toxicol. 40:88. doi: 10.1093/jat/bkv043

McIntyre, I. M., Trochta, A., Gary, R. D., Wright, J., and Mena, O. (2016b). An acute butyrfentanyl fatality: a case report with postmortem concentrations. $J$. Anal. Toxicol. 40, 162-166. doi: 10.1093/jat/bkv138

Melent'ev, A. B., Kataev, S. S., and Dvorskaya, O. N. (2015). Identification and analytical properties of acetyl fentanyl metabolites. J. Anal. Chem. 70, 240-248. doi: $10.1134 /$ S1061934815020124

Meuldermans, W., Van Peer, A., Hendrickx, J., Woestenborghs, R., Lauwers, W., Heykants, J., et al. (1988). Alfentanil pharmacokinetics and metabolism in humans. Anesthesiology 69, 527-534. doi: 10.1097/00000542-198810000-00012

Meyer, M. R., Dinger, J., Schwaninger, A. E., Wissenbach, D. K., Zapp, J., Fritschi, G., et al. (2012). Qualitative studies on the metabolism and the toxicological detection of the fentanyl-derived designer drugs 3methylfentanyl and isofentanyl in rats using liquid chromatography-linear ion 
trap-mass spectrometry (LC-MS N). Anal. Bioanal. Chem. 402, 1249-1255. doi: 10.1007/s00216-011-5528-8

Mohr, A. L., Friscia, M., Papsun, D., Kacinko, S. L., Buzby, D., and Logan, B. K. (2016). Analysis of novel synthetic opioids U-47700, U-50488 and furanyl fentanyl by LC-MS/MS in postmortem casework. J. Anal. Toxicol. 40, 709-717. doi: 10.1093/jat/bkw086

Montesano, C., Vannutelli, G., Fanti, F., Vincenti, F., Gregori, A., Rita Togna, A., et al. (2017). Identification of MT-45 metabolites: in silico prediction, in vitro incubation with rat hepatocytes and in vivo confirmation. J. Anal. Toxicol. 41, 688-697. doi: 10.1093/jat/bkx058

Moore, P. W., Palmer, R. B., and Donovan, J. W. (2015). Fatal fentanyl patch misuse in a hospitalized patient with a postmortem increase in fentanyl blood concentration. J. Forensic Sci. 60, 243-246. doi: 10.1111/1556-4029. 12559

Nielsen, M. K., Johansen, S. S., and Linnet, K. (2015). Evaluation of poly-drug use in methadone-related fatalities using segmental hair analysis. Forensic Sci. Int. 248, 134-139. doi: 10.1016/j.forsciint.2015.01.004

Niemegeers, C. J., Schellekens, K. H., Van Bever, W. F., and Janssen, P. A. (1976). Sufentanil, a very potent and extremely safe intravenous morphine-like compound in mice, rats and dogs. Arzneimittelforschung 26, 1551-1556.

O’Donnell, J. K., Halpin, J., Mattson, C. L., Goldberger, B. A., and Gladden, R. M. (2017). Deaths Involving Fentanyl, Fentanyl Analogs, and U-47700 - 10 States, July-December 2016. MMWMorbidity R Mortal. Weekly Report 66, 1197-1202.

Oertel, R., Pietsch, J., Arenz, N., Zeitz, S. G., Goltz, L., and Kirch, W. (2011). Distribution of metoprolol, tramadol, and midazolam in human autopsy material. J. Chromatogr. A 1218, 4988-94. doi: 10.1016/j.chroma.2010.12.113

Ogle, A., Moore, K., Barrett, B., Young, M. S., and Pearson, J. (2012). Clinical history and characteristics of persons with oxycodone-related deaths in hillsborough county, Florida in 2009. Forensic Sci. Int. 223, 47-52. doi: 10.1016/j.forsciint.2012.07.016

Ojanperä, I., Gergov, M., Rasanen, I., Lunetta, P., Toivonen, S., Tiainen, E., et al. (2006). Blood levels of 3-methylfentanyl in 3 fatal poisoning cases. American J. Forensic Med. Pathol. 27, 328-331. doi: 10.1097/01.paf.0000188097.78132.e5

Olson, K. N., Luckenbill, K., Thompson, J., Middleton, O., Geiselhart, R., Mills, K. M., et al. (2010). Postmortem redistribution of fentanyl in blood. Am. J. Clin. Pathol. 133, 447-453. doi: 10.1309/AJCP4X5VHF SOERFT

Palamalai, V., Olson, K. N., Kloss, J., Middleton, O., Mills, K., Strobl, A. Q., et al. (2013). Superiority of postmortem liver fentanyl concentrations over peripheral blood influenced by postmortem interval for determination of fentanyl toxicity. Clin. Biochem. 46, 598-602. doi: 10.1016/j.clinbiochem.2013.02.001

Papsun, D., Hawes, A., Mohr, A. L. A., Friscia, M., and Logan, B. K. (2017). Case series of novel illicit opioid-related deaths. Acad. Forensic Pathol. 7, 477-486. doi: $10.23907 / 2017.040$

Papsun, D., Krywanczyk, A., Vose, J. C., Bundock, E. A., and Logan, B. K. (2016). Analysis of MT-45, a novel synthetic opioid, in human whole blood by LC-MSMS and its identification in a drug-related death. J. Anal. Toxicol. 40, 313-317. doi: $10.1093 /$ jat/bkw012

Patanwala, A. E., Duby, J., Waters, D., and Erstad, B. L. (2007). Opioid conversions in acute care. Ann. Pharmacother. 41, 255-267. doi: 10.1345/aph.1H421

Pattinson, K. T. (2008). Opioids and the control of respiration. Br. J. Anaesth. 100, 747-58. doi: 10.1093/bja/aen094

Patton, A. L., Seely, K. A., Pulla, S., Rusch, N. J., Moran, C. L., Fantegrossi, W. E., et al. (2014). Quantitative measurement of acetyl fentanyl and acetyl norfentanyl in human urine by LC-MS/MS. Anal. Chem. 86, 1760-1766. doi: $10.1021 /$ ac4036197

Pearson, J., Poklis, J., Poklis, A., Wolf, C., Mainland, M., Hair, L., et al. (2015). Postmortem toxicology findings of acetyl fentanyl, fentanyl, and morphine in heroin fatalities in tampa, Florida. Acad. Forensic Pathol. 5, 676-689. doi: $10.23907 / 2015.072$

Pichini, S., Solimini, R., Berretta, P., Pacifici, R., and Busardò, F. P. (2018). Acute intoxications and fatalities from illicit fentanyl and analogues. Ther. Drug Monit. 40, 38-51. doi: 10.1097/FTD.0000000000000465

Pilgrim, J. L., McDonough, M., and Drummer, O. H. (2013). A review of methadone deaths between 2001 and 2005 in Victoria, Australia. Forensic Sci. Int. 226, 216-22. doi: 10.1016/j.forsciint.2013. 01.028
Poklis, J., Poklis, A., Wolf, C., Hathaway, C., Arbefeville, E., Chrostowski, L., et al. (2016). Two fatal intoxications involving butyryl fentanyl. J. Anal. Toxicol. 40, 703-708. doi: 10.1093/jat/bkw048

Poklis, J., Poklis, A., Wolf, C., Mainland, M., Hair, L., Devers, K., et al. (2015). Postmortem tissue distribution of acetyl fentanyl, fentanyl and their respective nor-metabolites analyzed by ultrahigh performance liquid chromatography with tandem mass spectrometry. Forensic Sci. Int. 257, 435-441. doi: 10.1016/j.forsciint.2015.10.021

Rodda, L. N., Pilgrim, J. L., Di Rago, M., Crump, K., Gerostamoulos, D., and Drummer, O. H. (2017). A cluster of fentanyl-laced heroin deaths in 2015 in Melbourne, Australia. J. Anal. Toxicol. 41, 318-324. doi: 10.1093/jat/ bkx013

Rohrig, T. P., Miller, S. A., and Baird, T. R. (2017). U-47700: a not so new opioid. J. Anal. Toxicol. 42, e12-e14. doi: 10.1093/jat/bkx081

Rojkiewicz, M., Majchrzak, M., Celinski, R., Kuś, P., and Sajewicz, M. (2017). Identification and physicochemical characterization of 4-fluorobutyrfentanyl (1-((4-Fluorophenyl)(1-Phenethylpiperidin-4-Yl)Amino)Butan-1-One, 4FBF) in seized materials and post-mortem biological samples. Drug Test. Anal. 9, 405-414. doi: 10.1002/dta.2135

Saitman, A., Fitzgerald, R. L., and McIntyre, I. M. (2015). Evaluation and comparison of postmortem hydrocodone concentrations in peripheral blood, central blood and liver specimens: a minimal potential for redistribution. Forensic Sci. Int. 247, 36-40. doi: 10.1016/j.forsciint.2014.11.031

Sato, S., Suzuki, S., Lee, X. P., and Sato, K. (2010). Studies on 1-(2-Phenethyl)4-(N-Propionylanilino)Piperidine (Fentanyl) and related compounds. vii. quantification of $\alpha$-methylfentanyl metabolites excreted in rat urine. Forensic Sci. Int. 195, 68-72. doi: 10.1016/j.forsciint.2009.11.014

Schneider, E., and Brune, K. (1986). Opioid activity and distribution of fentanyl metabolites. Naunyn Schmiedeberg's Arch. Pharmacol. 334, 267-274.

Scientific Working Group for Forensic Toxicology (2013). Scientific Working Group for Forensic Toxicology (SWGTOX) standard practices for method validation in forensic toxicology. J. Anal. Toxicol. 37, 452-474. doi: $10.1093 /$ jat/bkt054

Seldén, T., Ahlner, J., Druid, H., and Kronstrand, R. (2012). Toxicological and pathological findings in a series of buprenorphine related deaths. possible risk factors for fatal outcome. Forensic Sci. Int. 220, 284-90. doi: 10.1016/j.forsciint.2012.03.016

Seth, P., Scholl, L., Rudd, R. A., and Bacon, S. (2018). Overdose deaths involving opioids, cocaine, and psychostimulants - United States , 2015-2016. MMWR Morb. Mortal. Wkly. Rep. 67, 349-358 doi: 10.15585/mmwr.mm6712a1

Shanks, K. G., and Behonick, G. S. (2017). Detection of carfentanil by LC-MS-MS and reports of associated fatalities in the USA. J. Anal. Toxicol. 41, 466-472. doi: $10.1093 /$ jat/bkx042

Smith, H. S. (2009). Clinical pharmacology of oxymorphone. Pain Med. 10(Suppl. 1), S1-S10. doi: 10.1111/j.1526-4637.2009.00594.x

Soh, Y. N., and Elliot, S. (2014). An investigation of the stability of emerging new psychoactive substances. Drug Test. Anal. 6, 696-704. doi: 10.1002/dta.1576

Staeheli, S. N., Baumgartner, M. R., Gauthier, S., Gascho, D., Jarmer, J., Kraemer, T., et al. (2016). Time-dependent postmortem redistribution of butyrfentanyl and its metabolites in blood and alternative matrices in a case of butyrfentanyl intoxication. Forensic Sci. Int. 266, 170-177. doi: 10.1016/j.forsciint.2016.05.034

Staeheli, S. N., Gascho, D., Ebert, L. C., Kraemer, T., and Steuer, A. E. (2017). Timedependent postmortem redistribution of morphine and its metabolites in blood and alternative matrices-application of ct-guided biopsy sampling. Int. J. Legal Med. 131, 379-389. doi: 10.1007/s00414-016-1485-2

Steuer, A. E., Williner, E., Staeheli, S. N., and Kraemer, T. (2017). Studies on the metabolism of the fentanyl- derived designer drug butyrfentanyl in human in vitro liver preparations and authentic human samples using liquid chromatography-high resolution mass spectrometry (LC-HRMS). Drug Test. Anal. 9, 1085-1092. doi: 10.1002/dta.2111

Swanson, D. M., Hair, L. S., Strauch Rivers, S. R., Smyth, B. C., Brogan, S. C., Ventoso, A. D., et al. (2017). Fatalities involving carfentanil and furanyl fentanyl: two case reports. J. Anal. Toxicol. 41, 498-502. doi: 10.1093/jat/bkx037

Takase, I., Koizumi, T., Fujimoto, I., Yanai, A., and Fujimiya, T. (2016). An autopsy case of acetyl fentanyl intoxication caused by insufflation of 'Designer Drugs.' Legal Med. 21, 38-44. doi: 10.1016/j.legalmed.2016.05.006

Thaulow, C. H., Høiseth, G., Andersen, J. M., Handal, M., and Mørland, J. (2014). Pharmacokinetic interactions between ethanol and heroin: 
a study on post-mortem cases. Forensic Sci. Int. 242, 127-134. doi: $10.1016 /$ j.forsciint.2014.06.032

Ujváry, I., Jorge, R., Christie, R., Le Ruez, T., Danielsson, H. V., Kronstrand, R., et al. (2017). Acryloylfentanyl, a recently emerged new psychoactive substance: a comprehensive review. Forensic Toxicol. 35, 232-243. doi: 10.1007/s11419-017-0367-8

UNODC (2017). Recommended Methods for the Identification and Analysis of Fentanyl and Its Analogues in Biological Specimens (Vienna).

US Drug Enforcement Administration (2017). Drugs of Abuse 2017 Edition: A DEA Resource Guide. U.S. Department of Justice. Available online at: https://www. dea.gov/pr/multimedia-library/publications/drug_of_abuse.pdf

Van Bever, W. F., Niemegeers, C. J., Schellekens, K. H., and Janssen, P. A. (1976). N4-Substituted 1-(2-Arylethyl)-4-Piperidinyl-N-phenylpropanamides, a novel series of extremely potent analgesics with unusually high safety margin. Arzneimittelforschung. 26, 1548-1551.

Vardanyan, R. S., and Hruby, V. J. (2014). Fentanyl-related compounds and derivatives: curresnt status future prospects for pharmaceutical applications. Future Med. Chem. 6, 385-412. doi: 10.4155/fmc.13. 215

Vorce, S. P., Knittel, J. L., Holler, J. M., Magluilo, J., Levine, B., Berran, P., et al. (2014). A fatality involving Ah-7921. J. Anal. Toxicol. 38, 226-230. doi: $10.1093 /$ jat/bku011

Wang, L., and Bernert, J. T. (2006). Analysis of 13 fentanils , including sufentanil and caffentanii, in human urine by liquid ionization-tandem mass spectrometry *. J. Anal. Toxicol. 30, 335-341.

Watanabe, S., Vikingsson, S., Roman, M., Green, H., Kronstrand, R., and Wohlfarth, A. (2017). In vitro and in vivo metabolite identification studies for the new synthetic opioids acetylfentanyl, acrylfentanyl, furanylfentanyl, and 4-fluoro-isobutyrylfentanyl. AAPS J. 19, 1102-1122. doi: 10.1208/s12248-017-0070-z

Wax, P. M., Becker, C. E., and Curry, S. C. (2003). Unexpected 'Gas' casualties in Moscow: a medical toxicology perspective. Ann. Emerg. Med. 41, 700-705. doi: $10.1067 / \mathrm{mem} .2003 .148$

Wohlfarth, A., Scheidweiler, K. B., Pang, S., Zhu, M., Castaneto, M., Kronstrand, R., et al. (2016). Metabolic characterization of AH-7921, a synthetic opioid designer drug: in vitro metabolic stability assessment and metabolite identification, evaluation of in silico prediction, and in vivo confirmation. Drug Test. Anal. 8, 779-791. doi: 10.1002/dta.1856

Yonemitsu, K., Sasao, A., Mishima, S., Ohtsu, Y., and Nishitani, Y. (2016). A fatal poisoning case by intravenous injection of 'Bath Salts' containing acetyl fentanyl and 4-methoxy PV8. Forensic Sci. Int. 267, e6-e9. doi: 10.1016/j.forsciint.2016.08.025

Zawilska, J. B. (2017). An expanding world of novel psychoactive substances: opioids. Front. Psychiatry 8:110. doi: 10.3389/fpsyt.2017.00110

Conflict of Interest Statement: The authors declare that the research was conducted in the absence of any commercial or financial relationships that could be construed as a potential conflict of interest.

Copyright (c) 2018 Concheiro, Chesser, Pardi and Cooper. This is an open-access article distributed under the terms of the Creative Commons Attribution License (CC $B Y)$. The use, distribution or reproduction in other forums is permitted, provided the original author(s) and the copyright owner(s) are credited and that the original publication in this journal is cited, in accordance with accepted academic practice. No use, distribution or reproduction is permitted which does not comply with these terms. 